\title{
BMP/SMAD Pathway Promotes Neurogenesis of Midbrain Dopaminergic Neurons In Vivo and in Human Induced Pluripotent and Neural Stem Cells
}

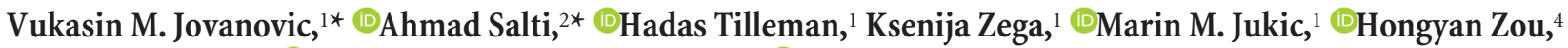 \\ Roland H. Friedel, ${ }^{4}$ ○Nilima Prakash, ${ }^{5}$ Sandra Blaess, ${ }^{6}{ }^{-}$Frank Edenhofer, ${ }^{2,3}$ and Claude Brodski ${ }^{1}$ \\ ${ }^{1}$ Department of Physiology and Cell Biology, Zlotowski Center for Neuroscience, Faculty of Health Sciences, Ben-Gurion University of the Negev, 84105 \\ Be'er Sheva, Israel, ${ }^{2}$ Institute of Molecular Biology and CMBI, Department of Genomics, Stem Cell Biology and Regenerative Medicine, Leopold Franzens \\ University Innsbruck, 6020 Innsbruck, Austria, ${ }^{3}$ Institute of Anatomy and Cell Biology, University of Wuerzburg, 97070 Wuerzburg, Germany, \\ ${ }^{4}$ Departments of Neuroscience and Neurosurgery, Friedman Brain Institute, Icahn School of Medicine at Mount Sinai, New York, New York 10029, \\ ${ }^{5}$ Department Hamm 2, Hamm-Lippstadt University of Applied Sciences, 59063 Hamm, Germany, and ${ }^{6}$ Institute of Reconstructive Neurobiology, University \\ of Bonn, 53127 Bonn, Germany
}

The embryonic formation of midbrain dopaminergic (mDA) neurons in vivo provides critical guidelines for the in vitro differentiation of mDA neurons from stem cells, which are currently being developed for Parkinson's disease cell replacement therapy. Bone morphogenetic protein (BMP)/SMAD inhibition is routinely used during early steps of stem cell differentiation protocols, including for the generation of $\mathrm{mDA}$ neurons. However, the function of the BMP/SMAD pathway for in vivo specification of mammalian mDA neurons is virtually unknown. Here, we report that BMP5/7-deficient mice $\left(B m p 5^{-/-} ; B m p 7^{-/-}\right)$lack mDA neurons due to reduced neurogenesis in the mDA progenitor domain. As molecular mechanisms accounting for these alterations in $B m p 5^{-/-} ; B m p 7^{-/-}$mutants, we have identified expression changes of the BMP/SMAD target genes MSX1/2 (msh homeobox 1/2) and SHH (sonic hedgehog). Conditionally inactivating SMAD1 in neural stem cells of mice in vivo (Smad1 ${ }^{\mathrm{Nes}}$ ) hampered the differentiation of progenitor cells into mDA neurons by preventing cell cycle exit, especially of $\mathrm{TH}^{+} \mathrm{SOX}^{+}{ }^{+}$(tyrosine hydroxylase, SRY-box 6) and $\mathrm{TH}^{+} \mathrm{GIRK}^{+}$(potassium voltage-gated channel subfamily-J member-6) substantia nigra neurons. BMP5/7 robustly increased the in vitro differentiation of human induced pluripotent stem cells and induced neural stem cells to mDA neurons by up to threefold. In conclusion, we have identified BMP/SMAD signaling as a novel critical pathway orchestrating essential steps of mammalian $\mathrm{mDA}$ neurogenesis in vivo that balances progenitor proliferation and differentiation. Moreover, we demonstrate the potential of BMPs to improve the generation of stem-cell-derived mDA neurons in vitro, highlighting the importance of sequential BMP/SMAD inhibition and activation in this process.

Key words: embryonic development; midbrain dopaminergic neurons; neurogenesis; neuronal differentiation; stem cells; iPSC

Significance Statement

We identify bone morphogenetic protein (BMP)/SMAD signaling as a novel essential pathway regulating the development of mammalian midbrain dopaminergic ( $\mathrm{mDA}$ ) neurons in vivo and provide insights into the molecular mechanisms of this process. BMP5/7 regulate MSX1/2 (msh homeobox 1/2) and SHH (sonic hedgehog) expression to direct mDA neurogenesis. Moreover, the BMP signaling component SMAD1 controls the differentiation of mDA progenitors, particularly to substantia nigra neurons, by directing their cell cycle exit. Importantly, BMP5/7 increase robustly the differentiation of human induced pluripotent and induced neural stem cells to mDA neurons. BMP/SMAD are routinely inhibited in initial stages of stem cell differentiation protocols currently being developed for Parkinson's disease cell replacement therapies. Therefore, our findings on opposing roles of the BMP/SMAD pathway during in vitro $\mathrm{mDA}$ neurogenesis might improve these procedures significantly. 


\section{Introduction}

The major dopaminergic nuclei, the substantia nigra (SN) and ventral tegmental area (VTA), are located in the midbrain and play essential roles in brain functions and disorders. The SN midbrain dopaminergic ( $\mathrm{mDA}$ ) neurons are particularly vulnerable to degeneration and their loss is characteristic of Parkinson's disease (PD) (Arenas et al., 2015). Stem-cell-derived mDA neurons are critical for modeling of $\mathrm{PD}$, drug screening, and cell replacement therapy. The differentiation of stem cells to $\mathrm{mDA}$ neurons requires the knowledge of the exact molecular mechanisms directing the embryonic development of $\mathrm{mDA}$ neurons in vivo.

After the induction of the ventral midbrain during embryogenesis, a distinct dopaminergic progenitor domain is specified. The anterior extension of the $\mathrm{mDA}$ progenitor domain is defined by the EN1/DBX1 microdomains (Nouri and Awatramani, 2017) and the posterior boundary is defined by the caudal border of the OTX2 expression domain at the mid-hindbrain junction. The dorsal-ventral borders are defined by LMX1A expression that overlaps with $\mathrm{SHH}$ (sonic hedgehog) expression of the midbrain floor plate. In this domain, progenitors divide symmetrically to expand their pool and switch to neurogenic division at the onset of neurogenesis (Veenvliet and Smidt, 2014; Arenas et al., 2015; Blaess and Ang, 2015). The balance between self-renewal and cell cycle exit of dopaminergic neural progenitors, and the generation of the appropriate numbers of postmitotic progeny is critical for the proper formation of $\mathrm{mDA}$ neurons. So far three major signaling pathways activated by $\mathrm{SHH}$, WNTs, and FGFs have been identified in mammals to control proliferation and specification of mDA progenitors in vivo (Ye et al., 1998; Prakash et al., 2006; Saarimäki-Vire et al., 2007; Joksimovic et al., 2009; Andersson et al., 2013; Blaess and Ang, 2015). These signaling pathways work in concert with a series of transcription factors including OTX2, LMX1B, LMX1A, EN1/2, FOXA1/2, NGN2, PITX3, MSX1/2, and NURR1, which are important for progenitor cell responsiveness to morphogens, differentiation, and survival (Zetterström et al., 1997; Smidt et al., 2000; Simon et al., 2001; Brodski et al., 2003; Puelles et al., 2003; Andersson et al., 2006a,b; Kele et al., 2006; Ferri et al., 2007; Blaess and Ang, 2015; Sherf et al., 2015). Although it has been postulated that additional signaling pathways might be involved in the generation of mDA neurons, their identity has remained elusive.

Significant progress has been made in the generation of stemcell-derived mDA neurons. However, essential parameters are still not fully controllable, including the consistency between experiments, phenotypic identity of progenitors, and purity of mDA neu-

Received June 1, 2017; revised Dec. 28, 2017; accepted Jan. 2, 2018.

Author contributions: V.M.J., F.E., and C.B. designed research; V.M.J., A.S., H.T., K.Z., and M.H.J. performed research; V.M.J., A.S., H.Z., R.H.F., N.P., S.B., F.E., and C.B. analyzed data; V.M.J. and C.B. wrote the paper.

This work was supported by the Israeli Science Foundation (Grant 1391/11 to C.B.), the Deutsche Forschungsgemeinschaft (DFG 79/4-1 to F.E.; DFG BL 767 / 2-1 and DFG BL 767 / 3-1 to SB), the Bavarian Research Network on Induced Pluripotent Stem Cells (For IPS to F.E.), the United States-Israel Binational Science Foundation (Grant 2015356 to C.B. and R.H.F), and the National Institute National Institute of Neurological Disorders and StrokeNational Institutes of Health (Grant R01 NS073596 to H.Z.). The SHH, NKX6.1, ISLET1/2, MSX1/2, and EN1 antibodies were obtained through the; Developmental Studies Hybridoma Bank under the auspices of the National Institute of Child Health and Human Development and maintained by The University of lowa (lowa City, IA). We thank Ze'ev Silverman for helpful discussions and critical reading of the manuscript and Lei Chen, Nicolas Daviaud, and Yong Huang in the Zou laboratory for help with the experiments.

*V.M.J. and A.S. contributed equally to this work.

Correspondence should be addressed to Claude Brodski, Department of Physiology and Cell Biology, Zlotowski Center for Neuroscience, Faculty of Health Sciences, Ben-Gurion University of the Negev, 84105 Be'er Sheva, Israel. E-mail: claude@bgu.ac.il.

DOI:10.1523/JNEUROSCI.1540-17.2018

Copyright $\odot 2018$ the authors $\quad 0270-6474 / 18 / 381663-15 \$ 15.00 / 0$ rons. Progress in the ability to determine these parameters are essential because they are linked directly to graft outcome, dyskinesia side effects, and potential tumor formation after transplantation (Politis et al., 2010; Arenas et al., 2015; Kirkeby et al., 2017). Current in vitro differentiation protocols are based on the activation of the three signaling pathways, $\mathrm{SHH}$, WNT and FGF, which regulate the formation of mammalian $\mathrm{mDA}$ neurons in vivo (Chambers et al., 2009; Kriks et al., 2011; Salti et al., 2013; Arenas et al., 2015). Therefore, the discovery of additional signaling pathways that determine $\mathrm{mDA}$ development in vivo could critically advance the abilities to manipulate in vitro conditions to achieve desired outcomes.

Bone morphogenetic proteins (BMPs) belong to the transforming growth factor $\beta$ superfamily. Phosphorylated SMAD1, SMAD5, and SMAD8 are the major intracellular BMP signaling pathway components. The BMP/SMAD pathway regulates a wide array of neurodevelopmental processes, including progenitor proliferation, apoptosis, and differentiation (Chen and Panchision, 2007; Bond et al., 2012; Hegarty et al., 2013). Depending on the cell type, extracellular environment, and developmental stage, they might enhance or inhibit these processes. A significant progress in the directed neural differentiation of human pluripotent stem cells was the discovery that blocking the BMP/SMAD pathway in initial steps of the protocol led to highly efficient neural conversion (Chambers et al., 2009; Kriks et al., 2011; Salti et al., 2013). However, the role of BMPs during later stages of mDA specification and maturation in vitro is unclear. Similarly, the in vivo role of BMP/SMAD signaling in the formation of mammalian mDA neurons is unknown. In the current study, we investigated the function of BMP5/6/7 and SMAD1 in the formation of $\mathrm{mDA}$ neurons in vivo. Moreover, we explored the potential of BMP5/7 in the directed differentiation of human stem cells to mDA neurons.

\section{Materials and Methods}

Mouse strains. The seGnJ mutation is a null allele at the Bmp5 locus (Kingsley et al., 1992). Mice were provided by the Jackson Laboratory and were genotyped as described previously (Solloway and Robertson, 1999). Bmp6- and Bmp7-deficient mice, kindly provided by Elizabeth J. Robertson, were generated, genotyped, and maintained on an outbred background as described previously (Solloway and Robertson, 1999; Dudley et al., 1995). Bmp5 $5^{-/-}$mice heterozygous for $B m p 7\left(B m p 7^{+/-}\right)$ were mated to obtain double homozygous $B m p 5^{-1-} ; B m p 7^{-1-}$ embryos. As a control, we used $B m p 5^{-1-} ; B m p 7^{+1-}$ mutants that have one intact $B m p 7$ allele and are viable and fertile. Smad $1^{\mathrm{fl} / \mathrm{fl}}$ mice were mated to Nestin-Cre;Smad1 ${ }^{+/-}$mice to generate $S m a d 11^{\mathrm{fl} /-}$;Nestin-Cre conditional mutant mice and control littermates (Tronche et al., 1999; Huang et al., 2002; Finelli et al., 2013). All mice were housed in a temperaturecontrolled $\left(21-23^{\circ} \mathrm{C}\right)$ environment under a $12 \mathrm{~h}$ light/dark cycle and had ad libitum access to food and water in a pathogen-free animal facility. All procedures and experimental protocols conducted on the animals were approved by the Institutional Animal Care and Ethics committee at Ben-Gurion University of the Negev (permit \#IL-53-09-2016).

Embedding and sectioning of the tissue. For cryo-embedding, embryos were processed by fixation in $4 \%$ paraformaldehyde for $\sim 5 \mathrm{~h}$ [embryonic day $9.5($ E9.5)/E10.5] or overnight [E12.5/postnatal day 0 (P0)/adult], washed in PBS, pH 7.4, for $3 \times 5 \mathrm{~min}$, and immersed in $15 \%$ and $30 \%$ sucrose PBS solution until the tissue sank. Tissue was then placed in molds with optimal cutting temperature medium for 10-15 min before freezing on a very thin layer of liquid nitrogen.

For paraffin embedding, after fixation, embryos were dehydrated by immersion in serial ethanol solutions $(50 \%, 70 \%, 80 \%, 90 \%$, and $2 \times$ $100 \%$ ), isopropanol, and toluene before being embedded in paraffin. Serial coronal or sagittal sections were subsequently cut on a cryostat $(14 \mu \mathrm{m})$ or microtome $(5 \mu \mathrm{m})$ and mounted on Superfrost microscope slides. 
Fluorescent/nonfluorescent immunochemistry. Microscope slides with cryosections were placed at room temperature for 15-20 min, immersed in ice-cold $100 \%$ ethanol for $10 \mathrm{~min}$, and washed $3 \times 5$ min with PBS, $\mathrm{pH}$ 7.4, before incubation in blocking solution. Sections of the paraffinembedded tissue were rehydrated through a xylene and ethanol series and washed with PBS, pH 7.4. Antigen retrieval was performed in the next step using $0.001 \mathrm{M}$ citric acid solution for $10 \mathrm{~min}$ at $95^{\circ} \mathrm{C}$ before incubation in blocking solution. The incubation with primary antibodies was done overnight at $4^{\circ} \mathrm{C}$. Slides were then rinsed in PBS $(3 \times 5 \mathrm{~min})$ and incubated for $1 \mathrm{~h}$ at room temperature with secondary antibodies (Jackson ImmunoResearch) and DAPI (Sigma-Aldrich). HRP-DAB staining kit (CTS 019; R\&D Systems) was used for nonfluorescent BMP5 immunohistochemistry.

For the in vitro cultures, cells plated on glass coverslips were washed in $0.1 \mathrm{~m}$ PBS and fixed in 4\% paraformaldehyde dissolved in $0.1 \mathrm{~m}$ PBS. After washing, the cells were permeabilized with $0.3 \%$ Triton X-100 in $0.1 \mathrm{M}$ PBS for $15 \mathrm{~min}$ and then incubated for $1 \mathrm{~h}$ in the blocking solution containing $0.025 \%$ Triton X-100 and $10 \%$ fetal bovine serum (Invitrogen) in $0.1 \mathrm{M}$ PBS. Subsequently, cells were incubated overnight at $4^{\circ} \mathrm{C}$ with the primary antibodies diluted in the blocking solution containing $0.025 \%$ Triton X-100 and 5\% fetal bovine serum in $0.1 \mathrm{M}$ PBS. On the next day, cells were washed in $0.1 \mathrm{M}$ PBS/ $0.025 \%$ Triton X-100 (PBST) and incubated with the corresponding fluorescent secondary antibodies (Thermo Fisher Scientific). After washing with PBST, the cell nuclei were stained with DAPI for $5 \mathrm{~min}$ and then washed again with distilled water. Finally, coverslips were mounted onto adhesive slides using Aquapolymount (Polyscience). For DAT and GIRK2 staining, no permeabilization was needed and Triton X-100 was omitted in all solutions.

Primary antibodies. Primary antibodies used for the in vivo study were as follows: mouse anti-SHH (1:10), mouse anti-NKX6.1 (1:10), mouse anti-ISLET1/2 (1:10), mouse anti-MSX1/2 (1:10), mouse anti-FOXA2 (1:10), mouse anti-NESTIN (1:10), mouse anti-EN1 (1:50) - all from DSHB, rabbit anti-LMX1A (1:400, catalog \#AB10533; Millipore), rabbit anti-LMX1B (1:1000, gift from Dr. C. Birchmeier, MDC, Berlin), rabbit anti-NURR1 (1:100, catalog \#SC991; Santa Cruz Biotechnology), mouse anti-NURR1 (1:100, catalog \#376984; Santa Cruz Biotechnology) mouse anti-neurogenin-2 (1:800, catalog \#MAB3314; R\&D Systems), rabbit anti-TH (1:200, catalog \#AB152; Millipore), mouse anti-TH (1:200, catalog \#MAB318; Millipore), rabbit anti-phospho-SMAD1/5/8 (1:200, \#9511S Cell Signaling), sheep anti-BMP5 (1:10, catalog \#AF6176; R\&D Systems), rabbit anti-phospho-histone-H3 (1:1000, catalog \#06570; Millipore), rabbit anti-phospho-P38 (1:1000, catalog \#4511 Cell Signaling), rabbit anti-GIRK2 (1:200, catalog \#APC-006; Alomone Laboratories), rabbit anti-SOX6 (1:500, catalog \#ab30455; Abcam), mouse anti-POU4F1 (1:300, catalog \#sc8429; Santa Cruz Biotechnology), mouse anti-N-cadherin (1:200, catalog \#610920; BD Biosciences), rabbit anti-ZO1 (1:100, catalog \#40-2200; Invitrogen), rabbit anti-KI67 (1:100, catalog \# ab16667; Abcam), rabbit anti-cleaved-caspase 3 (1:100, catalog \#3661; Cell Signaling Technology), rabbit anti-MAP-2 (1:200, catalog \#sc20172; Santa Cruz Biotechnology), rabbit anti- $\beta$-catenin (1:400, catalog \#9587s; Cell Signaling Technology), rabbit anti-SHH (1:50, catalog \#sc9024; Santa Cruz Biotechnology), rabbit anti-BMPR1B (1:100, catalog \#10537; Orbigen), rabbit anti-PITX3 (catalog \#38-2850; Thermo Fisher Scientific), mouse anti-BrdU (catalog \#B2531; Sigma-Aldrich), rabbit antiCCND1(1:150, catalog \#sc-450; Santa Cruz Biotechnology), rabbit antiphospho- $\beta$-catenin (1:200, catalog \#9561s; Cell Signaling Technology), rabbit anti-calbindin (1:500, catalog \#D-28k; Swant), and rabbit anti- $\beta$ III tubulin/TUJ1 (1:500, catalog \#302 302; Synaptic Systems).

For the in vitro study, the following primary antibodies were used: mouse anti-TH (1:1000, catalog \#MAB318; Millipore), rabbit anti-TH (1:1000, catalog \#ab112; Abcam), rat anti-DAT (1:50, catalog \#sc-32259; SCBT), rabbit anti-LMX1A (1:1000, catalog \# ab10533; Millipore), goat anti-GIRK2 (1:200, catalog \#ab65096; Abcam), and rabbit anti-calbindin (1:1000, catalog \#CB38; Swant).

In situ hybridization. For radioactive in situ hybridization, all sections were processed according to Sherf et al. (2015) using ${ }^{35}$ S-labeled riboprobes against Bmp5, Bmp6, Bmp7, Th, Dat, and Nurr1.

For DIG-labeled in situ hybridization, mRNA probes were used to detect Bmp7 and Wnt1 mRNA (Sherf et al., 2015, Tilleman et al., 2010).
Sections were postfixed in ice-cold 4\% PFA for 10 min, digested with proteinase $\mathrm{K}(2 \mu \mathrm{g} / \mathrm{ml}, 50 \mathrm{~mm}$ Tris, $\mathrm{pH} 8,4 \mathrm{~mm}$ EDTA $)$ before acetylation ( $1.3 \%$ TEA, $0.3 \% 10 \mathrm{M} \mathrm{HCl}, 0.5 \%$ acetic anhydride in DEPC-treated water, $10 \mathrm{~min}$ ), and permeabilized with PBT for $30 \mathrm{~min}$. Prehybridization was done for $2 \mathrm{~h}$ at $65^{\circ} \mathrm{C}$ and hybridization was done overnight at $65^{\circ} \mathrm{C}$. Approximately $10 \mathrm{ng}$ of probe was added to $200 \mu \mathrm{l}$ of hybridization solution per slide. The next day, slides were incubated with antidigoxigenin antibody at $4^{\circ} \mathrm{C}$ overnight. NBT/BCIP (Roche) was used for color development.

In vivo proliferation assay. Pregnant females received intraperitoneal injection of BrdU dissolved in $0.9 \% \mathrm{NaCl}(100 \mathrm{mg} / \mathrm{kg}$; B5002; SigmaAldrich) $1 \mathrm{~h}$ before collection of embryos.

Quitting fraction. Twenty-four hours before harvesting embryos, pregnant females (E11.5) received intraperitoneal injection of BrdU (100 $\mathrm{mg} / \mathrm{kg}$; Sigma-Aldrich). Sections from E12.5 embryos were then triple stained for KI67, BrdU, and LMX1A. The quitting fraction was obtained by dividing the number of BrdU-labeled cells that had left the cell cycle $\left(\mathrm{KI}_{67}{ }^{-} \mathrm{BrdU}^{+} \mathrm{LMX1A}^{+}\right)$by the number of BrdU labeled cells that were still cycling $\left(\mathrm{KI}_{67}{ }^{+} \mathrm{BrdU}^{+} \mathrm{LMX1A}^{+}\right)$.

Area ratio analysis. $\mathrm{MAP}-2^{+}, \mathrm{KI}_{67}{ }^{+}$, and total midbrain area were marked throughout the midbrain and measured using ImageJ software and the values obtained were used to calculate MAP- $2^{+} /$total midbrain and $\mathrm{KI}_{67}{ }^{+}$/total midbrain ratios.

Cell density ratio analysis. For the cell density ratio analysis, a box was drawn perpendicular to the ventricular surface next to $\mathrm{mDA}$ domain of the midbrain. The box was divided in half to separate the neural tube wall to apical and basal side. Each half of the box area was measured in ImageJ software. DAPI ${ }^{+}$nuclei were counted within each half of the box, rostral to caudal throughout the midbrain, and divided by its area to obtain density values for apical and basal side. Apical density was divided by basal density to obtain density ratio between the two.

Total fluorescence intensity of SHH and $\beta$-catenin. For total immunofluorescence intensity of $\mathrm{SHH}$, a box was placed on the ventral midline throughout rostral to caudal sections of the midbrain. Area, integrated density, and mean gray value were measured using ImageJ software. A box of the same size was placed directly adjacent to the SHH expression domain and measurement was repeated. The total fluorescence intensity ratio was then calculated by the formula Integrated Density of box1/ Integrated density of box2 (Burgess, 2010). For the total immunofluorescence intensity measurements of $\beta$-catenin, the $\mathrm{mDA}$ domain constrained by NKX6.1 expression was outlined throughout the ventral midbrain and the same parameters were measured. Integrated density was normalized to area and background was subtracted for each image.

Cell culture. The derivation of the human induced pluripotent stem cell (iPSC) and the human directly induced neural stem cells (iNSC) lines has been described previously (Thier et al. 2012; Kadari et al., 2014; Meyer et al., 2015; Kwok et al., 2017). The human fibroblasts used in this study were obtained from a male individual skin punch biopsy after obtaining informed consent and ethical clearance by the ethics committee of the University of Würzburg (ethical report \#96/11, dated 10 June 2011) or from commercial sources (male foreskin). NSCs were generated from iPSCs as described in Reinhardt (2013). Both NSC-derived iPSCs and iNSCs were kept on growth factor-reduced Matrigel (Corning)coated plates in neural expansion medium consisting of 50:50 DMEMF12/Neurobasal medium with 1:50 B27 without vitamin A, 1:100 N2, 2 mM L-glutamine (all from; Invitrogen), $200 \mu \mathrm{M}$ ascorbic acid (SigmaAldrich), $18 \mathrm{~g} / \mathrm{ml}$ bovine serum albumin BSA fraction V (Applichem) and supplemented with $4 \mu \mathrm{M}$ CHIR99021 (Axon Medchem), $5 \mu \mathrm{M}$ Alk5 inhibitor (Enzo), and $0.5 \mu \mathrm{M}$ purmorphamine (Miltenyi Biotec).

To generate mDA neurons, neural expansion medium was changed $2 \mathrm{~d}$ after splitting to dopaminergic differentiation medium consisting of 50:50 DMEM-F12/Neurobasal with 1:50 B27 with vitamin A, $2 \mathrm{~mm}$ L-glutamine, $200 \mu \mathrm{M}$ ascorbic acid, and supplemented with $100 \mathrm{ng} / \mu \mathrm{l}$ FGF8 (PeproTech) and $1 \mu \mathrm{M}$ purmorphamine. When confluent, cells were split using Accutase (Thermo Fisher Scientific) and 30,000 cells were seeded in each well of a 12 well plate. Maturation started after $8 \mathrm{~d}$ by withdrawal of FGF8 and the addition of $10 \mathrm{ng} / \mathrm{ml} \mathrm{BDNF}$ (Stem Cell Technologies), 10 ng/ml GDNF (PeproTech), 1 ng/ml TGF-beta3 (PeproTech), and $500 \mu \mathrm{m}$ dbcAMP. Then, $0.5 \mu \mathrm{M}$ purmorphamine was added 
to this medium for 2 more days. In the BMP-or Noggin-treated cultures, $10 \mathrm{ng} / \mathrm{ml} \mathrm{BMP5}$ and BMP7 or $200 \mathrm{ng} / \mathrm{ml}$ Noggin (all from R\&D Systems) were added to the medium. Cultures were analyzed $30 \mathrm{~d}$ after the start of the differentiation ( $22 \mathrm{~d}$ in maturation conditions).

Cell quantification. For the in vivo studies paraffin-embedded coronal sections of E10.5 embryos ( $5 \mu \mathrm{m}$ thick; 4 series), E12.5 embryos ( $5 \mu \mathrm{m}$ thick; 6 series), E14.5 embryos ( $5 \mu \mathrm{m}$ thick, 6 series), and P0 brains ( $5 \mu \mathrm{m}$ thick; 8 series) were used for cell quantification experiments. Representative midbrain coronal sections revealing the distributions indicated are presented in the figures. All positive/double-positive cells on every fourth section (E10.5), sixth section (E12.5 and E14.5), or eighth section (P0) were counted. All values were normalized to WT average (100\%). ImageJ software was used for cell counting.

For the in vitro studies, the stained cells were observed using a motorized Leica DMi8 fluorescent inverted microscope equipped with a Hamamatsu Orca Flash 4.0 V2 camera. The numbers of $\mathrm{TH}^{+} \mathrm{TUJ}^{+}$, $\mathrm{LMX} 1 \mathrm{~A}^{+} \mathrm{TH}^{+}, \mathrm{TH}^{+} \mathrm{GIRK}_{2}{ }^{+}$, and $\mathrm{TH}^{+}{ }^{+} \mathrm{CALB}^{+}$cells were determined using Leica LasX and ImageJ software. From each experiment $(n=2-4)$, 2 coverslips were analyzed and at least 7 random areas per coverslip were counted. The number of quantified neurons for each experiment and each condition was between 1000 and 3000 .

Statistical analysis and experimental design. For both in vivo and in vitro studies, two-tailed unpaired Student's $t$ test was used for the comparison of the mean values. In the figures, ${ }^{\star} p<0.05$, ${ }^{* *} p<0.01$, and ${ }^{\star * *} p<$ 0.001 . Error bars represent SEM in all bar graphs. $t$ values $(t)$ and degrees of freedom (df) are specified for each $p$-value reported in the Results.

For the in vivo studies, the number of experimental replicates $(n)$ was at least 3 ( $n=3$ mutants $/ n=3 \mathrm{WT}$ controls). In vivo experiments with different $n$ values are specified in the Results.

For the in vitro studies, the number of replicates was at least 2 . For TH/TUJ1 counting, 4 experiments from iPSC\#1, 2 from iPSC\#2, and 2 from iNSCs were performed.

\section{Results \\ BMP5/7 are necessary for the generation of postmitotic mDA neurons}

To study the role of BMPs in mDA development, we first determined the expression of BMP5, BMP6, and BMP7 in the ventral midbrain. To do this, we used mRNA in situ hybridization and immunohistochemistry of WT embryos at different embryonic days. During mDA neurogenesis at E12.5, Bmp5, Bmp6, and $B m p 7$ mRNAs were strongly expressed at the mesencephalic flexure where mDA neurons are formed (Fig. $1 A-C$ ). The BMP receptor 1B (BMPR1B), which plays a critical role in neuronal differentiation (Panchision et al., 2001), was confined to the NKX6.1-negative mDA domain at E12.5 (Fig. 1D). Also before the onset of mDA neurogenesis at E10.5, Bmp7 mRNA expression, BMP5 immunoreactivity and phosphorylated SMAD-1/5/8 ( $\mathrm{p}$-SMAD1/5/8) were detected in the ventral midbrain close to and within the mDA progenitor domain (Fig. $1 E-G$ ), suggesting a role of these morphogens and SMAD1/5/8 in the formation of mDA neurons.

To assess the function of BMP signaling in the development of $\mathrm{mDA}$ neurons, we analyzed the formation of these neurons in different Bmp single and compound mouse mutants. Changes were not apparent in the formation of $\mathrm{mDA}$ neurons in $B m p 5^{-l-}, B m p 6^{-1-}$, and $B m p 7^{-1-}$ single mutants (Fig. $1 H-J^{\prime}$ ), nor in $B m p 5^{-I-} ; B m p 6^{-I-}$ and $B m p 6^{-I-} ; B m p 7^{-I-}$ compound mutants (Fig. $1 K-L^{\prime}$ ). In $B m p 5^{-l-} ; B m p 7^{-l-}$ compound mutants, however, postmitotic mDA neurons, marked by a highly sensitive radioactive mRNA in situ hybridization probe (Fig. $\left.1 M, M^{\prime}\right)$ and NURR1 immunoreactivity (Fig. $\left.1 N-O^{\prime \prime}\right)$, as well as $\beta$-III tubulin TUJ1 $\left(N-\mathrm{O}^{\prime \prime}\right)$, were entirely absent.

$B m p 5^{-1-} ; B m p 7^{-1-}$ mutants could not be studied after E10.5 because most embryos subsequently die from heart defects, as reported previously (Solloway and Robertson, 1999). Although
$B m p 5^{-1-} ; B m p 7^{-1-}$ embryos are smaller in size, they do not display an overall delay in development and contain the same number of somite pairs as controls (Solloway and Robertson, 1999). The absence of general patterning or regionalization defects in the ventral midbrain and midbrain-hindbrain regions was further demonstrated by normal Shh, Wht1, and Fgf8 expression in the midbrain floor plate and mid-hindbrain region at E10.5 (Solloway and Robertson, 1999). In addition, Phox 2 a mRNA expression in cranial nerves III and IV, which form directly adjacent to the mDA neurons at E9.5 (Pattyn et al., 1997), did not show delayed onset of expression in mutants compared with WT (Tilleman et al., 2010). Using ISLET-1/2 immunoreactivity to visualize the nuclei of cranial nerve III, we observed a normal induction of this nuclei at E9.5 (Fig. $1 P, P^{\prime}$ ), providing further evidence that the lack of NURR1 expression in $B m p 5^{-1-}$; $B m p 7^{-1-}$ mutants is not caused by a general delay in neurogenesis in the ventral midbrain. Together, our data support the conclusion that $\mathrm{BMP} 5 / 7$ are required for the formation of $\mathrm{mDA}$ neurons.

\section{BMP5/7 promote proliferation of $\mathrm{mDA}$ progenitors}

To investigate the mechanisms underlying the lack of postmitotic mDA neurons in $B m p 5^{-/-} ; B m p 7^{-/-}$embryos, we next studied the identity and relative extent of the $\mathrm{mDA}$ progenitor domain. Previous experiments indicated that, although $B m p 5^{-1-}$; $B m p 7^{-1-}$ embryos develop neurulation defects (Solloway and Robertson, 1999), patterning abnormalities are not observed in the floor plate, as visualized by Shh mRNA expression, or the mid-hindbrain organizer, as visualized by Wnt1 and Fgf 8 mRNA expression (Solloway and Robertson, 1999).

At E9.5 and E10.5, expression patterns of LMX1B and LMX1A, which mark the mDA progenitor domain, showed as in WT a clear boundary to the adjacent NKX6.1 ${ }^{+}$red nucleus progenitor population (Fig. $2 A-C^{\prime}$ ).

Although boundary relationships were intact in the ventral midbrain of $B m p 5^{-1-} ; B m p 7^{-1-}$ mutants, the mDA progenitor population, marked by $\mathrm{LMX}_{1 \mathrm{~A}}{ }^{+}$cells, was reduced by $39 \%$ at E10.5 (Fig. $2 C-C^{\prime \prime} ; t_{(4)}=2.89,{ }^{*} p=0.044$ ). We then determined whether the reduction in the number of $\mathrm{mDA}$ progenitor cells is due to a proliferation defect or cell death. A reduction of $45 \%$ of mitotic cells positive for LMX1A and phospho-histone $\mathrm{H} 3$ (PH3) (Fig. $2 D-D^{\prime \prime}, t_{(4)}=2.78,{ }^{*} p=0.049$ ) in the mDA progenitor domain of $B m p 5^{-/-} ; B m p 7^{-/-}$embryos at E10.5 indicated a proliferation defect in mutants. These findings were supported by a $35 \%$ reduction of cells in the S-phase of the cell cycle that were positive for both LMX1A and BrdU incorporation in mutants (Fig. $2 E-E^{\prime \prime}, t_{(4)}=2.83,{ }^{\star} p=0.047$ ), as well as a reduced number $\mathrm{KI} 7^{+}$cells, all of which were LMX1A positive (data not shown). In contrast, there was no increase in the levels of apoptosis in these mutants (Fig. 2G, $G^{\prime}$ ).

In the midbrain, but outside of the $\mathrm{mDA}$ progenitor domain of $B m p 5^{-1-} ; B m p 7^{-1-}$ mutants, the number of mitotic cells $\left(\mathrm{LMX} 1 \mathrm{~A}^{-} \mathrm{PH} 3^{+}\right.$) was not significantly different from WT, but showed a trend toward a decrease (Fig. $2 H-H^{\prime \prime} ; t_{(4)}=1.38, p=$ $0.24)$. In contrast to WT embryos, in which $\mathrm{BrdU}^{+}$cells were distributed evenly along the apicobasal extension of the neural tube wall, in $B m p 5^{-1-} ; B m p 7^{-1-}$ mutants, $\mathrm{BrdU}^{+}$and $\mathrm{Ki}^{+}$ cells clearly accumulated at the ventricular side of the neural tube, leaving a BrdU/Ki67-negative territory on the basal side (Fig. $\left.2 I-J^{\prime}\right)$. Dividing the area covered by $\mathrm{Ki}^{+}{ }^{+}$cells by the total midbrain area indicated that the $\mathrm{Ki}^{+}{ }^{+}$share in total midbrain area was reduced by $13 \%$, suggesting a depletion of the progenitor pool in mutants (Fig. $2 J^{\prime \prime} ; t_{(4)}=3.76,{ }^{\star} p=0.02$ ). To rule out the 

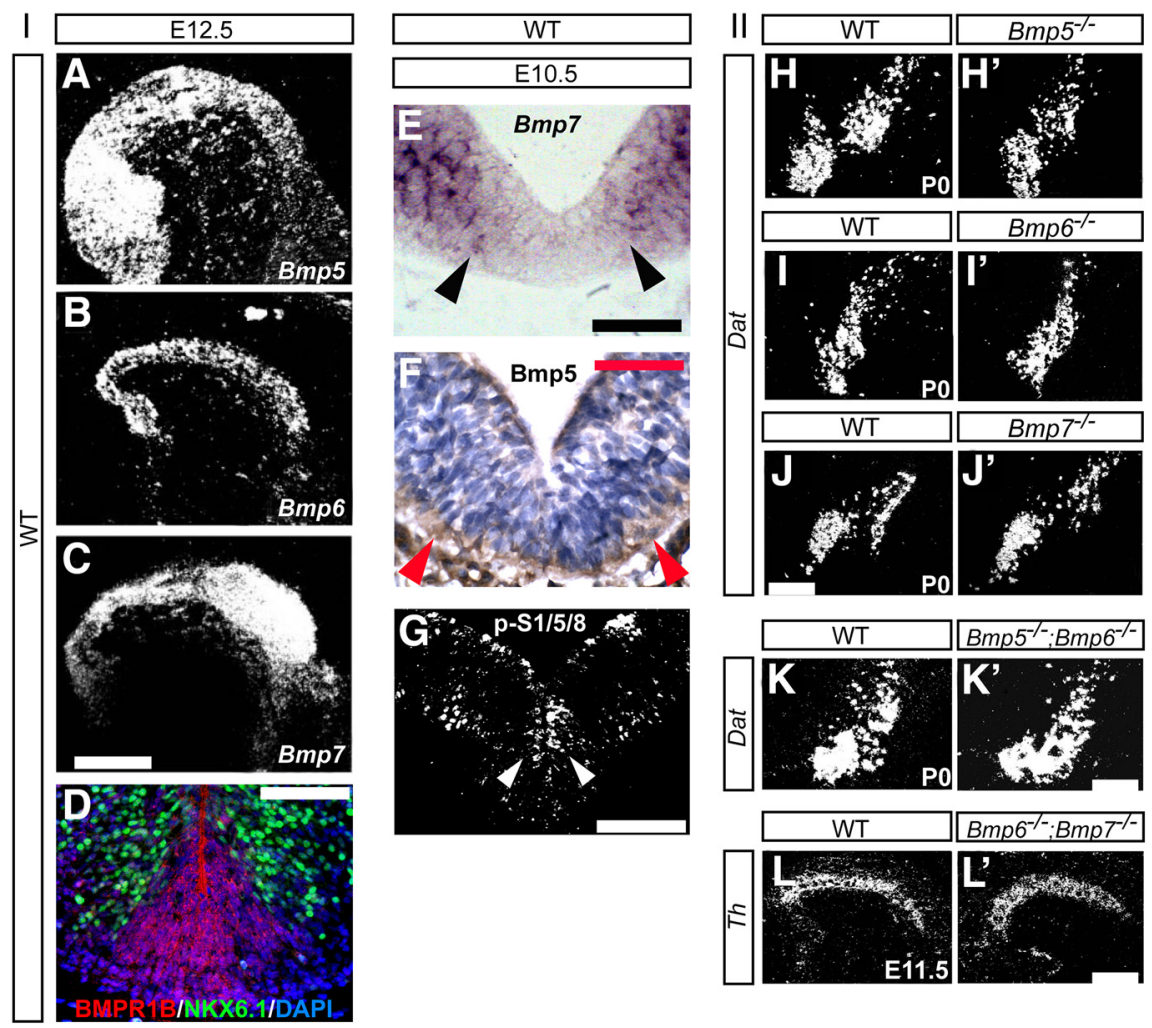

III
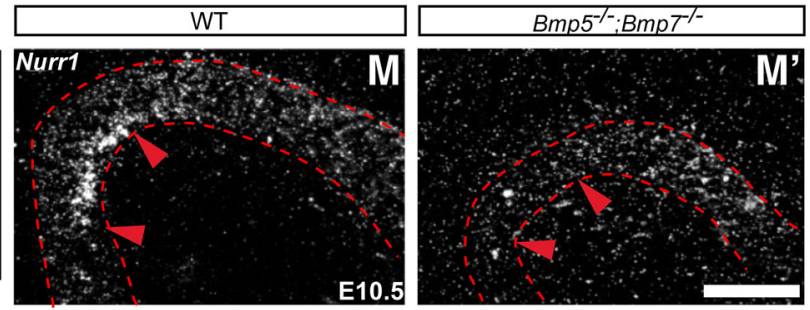

WT
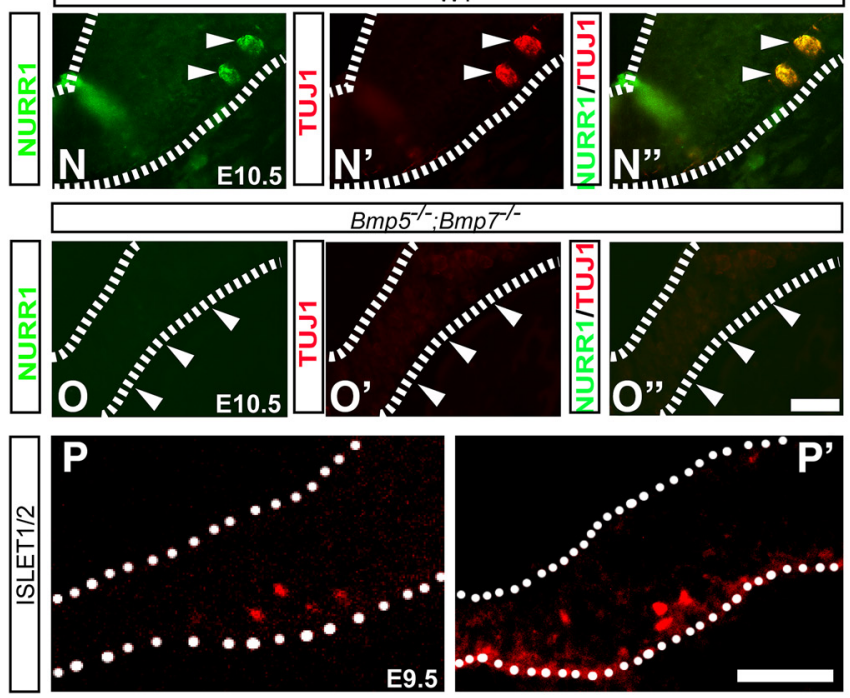

Figure 1. BMP5/7 are necessary for the generation of postmitotic mDA neurons. mRNA in situ hybridization $\left(\boldsymbol{A}-\boldsymbol{C}, \boldsymbol{E}, \boldsymbol{H}-\boldsymbol{M}^{\prime}\right)$ and immunohistochemistry $\left(\boldsymbol{D}, \boldsymbol{F}, \boldsymbol{G}, \boldsymbol{N}-\boldsymbol{P}^{\prime}\right)$ on parasagittal $\left(\boldsymbol{A}-\boldsymbol{C}, \boldsymbol{H}-\boldsymbol{M}^{\prime}\right)$ and coronal $\left(\boldsymbol{D}-\mathbf{G}, \boldsymbol{N}-\boldsymbol{P}^{\prime}\right)$ sections of the mesencephalic flexure at different developmental ages are represented. $B m p 5(\boldsymbol{A}), B m p 6(\boldsymbol{B})$, and $B m p 7(\boldsymbol{C})$ mRNAs are expressed at the mesencephalic flexure at E12.5. At the same developmental time point, BMPR1B is expressed specifically in the mDA progenitor domain (D). At E10.5, Bmp7 mRNA is expressed lateral to the midline in the mDA progenitor domain (E). Red arrows indicate BMP5 immunoreactivity in the pial surface and mantle layer of $\mathrm{mDA}$ progenitor domain $(\boldsymbol{F})$. White arrowheads point to cluster of cells with phosphorylated SMAD-1/5/8 (p-S1/5/8) immunoreactivity within the mDA progenitor domain (G). Single Bmp5, Bmp6, and Bmp7 gene deletion does not affect the formation of mDA neurons, as shown by the comparison of Dat mRNA expression on parasagittal sections of WT

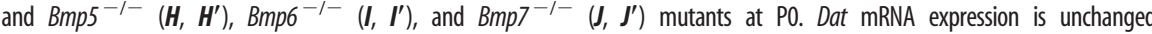

possibility that this was caused by disproportional density of the cells between the apical and basal side of the neural tube in $B m p 5^{-1-} ; B m p 7^{-1-}$ mutants, we measured the density of cell nuclei $\left(\mathrm{DAPI}^{+}\right)$ nuclei on the apical side (area 1) and basal side (area 2 ) adjacent to the mDA progenitor domain. No difference in the density ratio between the two was observed (Fig. $\left.2 K-K^{\prime \prime}, t_{(4)}=0.55, p=0.61\right)$. The altered distribution of progenitor cells suggests premature neurogenesis in the basal plate progenitor domain. However, these changes were not observed in the mDA progenitor domain (Fig. $2 F, F^{\prime}$ ). As for the rest of the midbrain, we did not observe changes in apoptosis in the basal plate of the mutant embryo (Fig. $2 L, L^{\prime}$ ). In summary, BMP5/7 control proliferation of progenitor cells in the mDA progenitor domain.

BMP5/7 are required for the induction of MSX1/2 and mDA neurogenesis

We subsequently assessed neurogenesis in the mDA progenitor domain of $B m p 5^{-/-} ; B m p 7^{-/-}$mutants by visualizing the proneuronal transcription factors MSX1/2, which are a direct downstream targets of the BMP signaling cascade (Timmer et al., 2002; Tribulo et al., 2003), and NGN2 (official gene symbol Neurog2, MGI). These factors play a critical role in the generation of $\mathrm{mDA}$ neurons (Andersson et al., 2006a,b; Kele et al., 2006). Consistent with previous reports (Andersson et al., 2006a,b; Kele et al., 2006), we found in the ventral midbrain MSX1/2 specifically expressed in the mDA progenitor domain (Fig. $3 A$ ). We observed an $86 \%$ reduction in the number of $\mathrm{MSX} 1 / 2^{+}$cells even after normalization to the number of LMX1A ${ }^{+}$cells (Fig. $\left.3 A-A^{\prime \prime}, t_{(4)}=9.4,{ }^{* * *} p=0.00071\right)$. Likewise, NGN2 ${ }^{+}$cells in the mDA progenitor domain of $B m p 5^{-1-} ; B m p 7^{-1-}$ mutants were also reduced by $74 \%$ after normalization to the number of $\mathrm{LMX}^{+} \mathrm{A}^{+}$ cells (Fig. $3 B-B^{\prime \prime}, t_{(4)}=14.44,{ }^{* * *} p=$ 0.000134). Moreover, Bmp5 $5^{-/-} ; B m p 7^{-1-}$

\footnotetext{
in Bmp5 $5^{-1-; B m p 6-I-}$ mutants at P0 $\left(\boldsymbol{K}, \boldsymbol{K}^{\prime}\right) . B m p 6^{-/}$

$B m p 7^{-1-}$ mutants did not show any obvious alterations in mDA development, as indicated by normal Th mRNA expression at $\mathrm{E} 11.5\left(\boldsymbol{L}, \mathbf{L}^{\prime}\right)$. In contrast, in $B m p 5^{-1-} ; B m p 7^{-/-} \mathrm{mu}-$ tants at E10.5, Nurr1 mRNA $\left(\boldsymbol{M}, \boldsymbol{M}^{\prime}\right)$ and NURR1 $\left(\boldsymbol{N}-\mathbf{O}^{\prime \prime}\right)$ immunoreactivity were absent. In addition, the postmitotic neuronal marker TUJ1 was coexpressed in NURR ${ }^{+}$cells at this time point in WT $\left(\boldsymbol{N}-\boldsymbol{N}^{\prime \prime \prime}\right)$. Adjacent ocular motor neurons visualized by ISLET1/2 immunoreactivity were normally induced in mutants at E9.5 $\left(\boldsymbol{P}^{\prime}\right)$ compared to WTs (P). Scale bars: $\boldsymbol{A}-\boldsymbol{D}, \mathbf{G}-\boldsymbol{L}^{\prime} 100 \mu \mathrm{m} . \mathbf{G}, \boldsymbol{P}, \boldsymbol{P}^{\prime} ; 25 \mu \mathrm{m} . \boldsymbol{E}, \boldsymbol{F}, \mathbf{N}-\boldsymbol{O}^{\prime} 25 \mu \mathrm{m}$.
} 

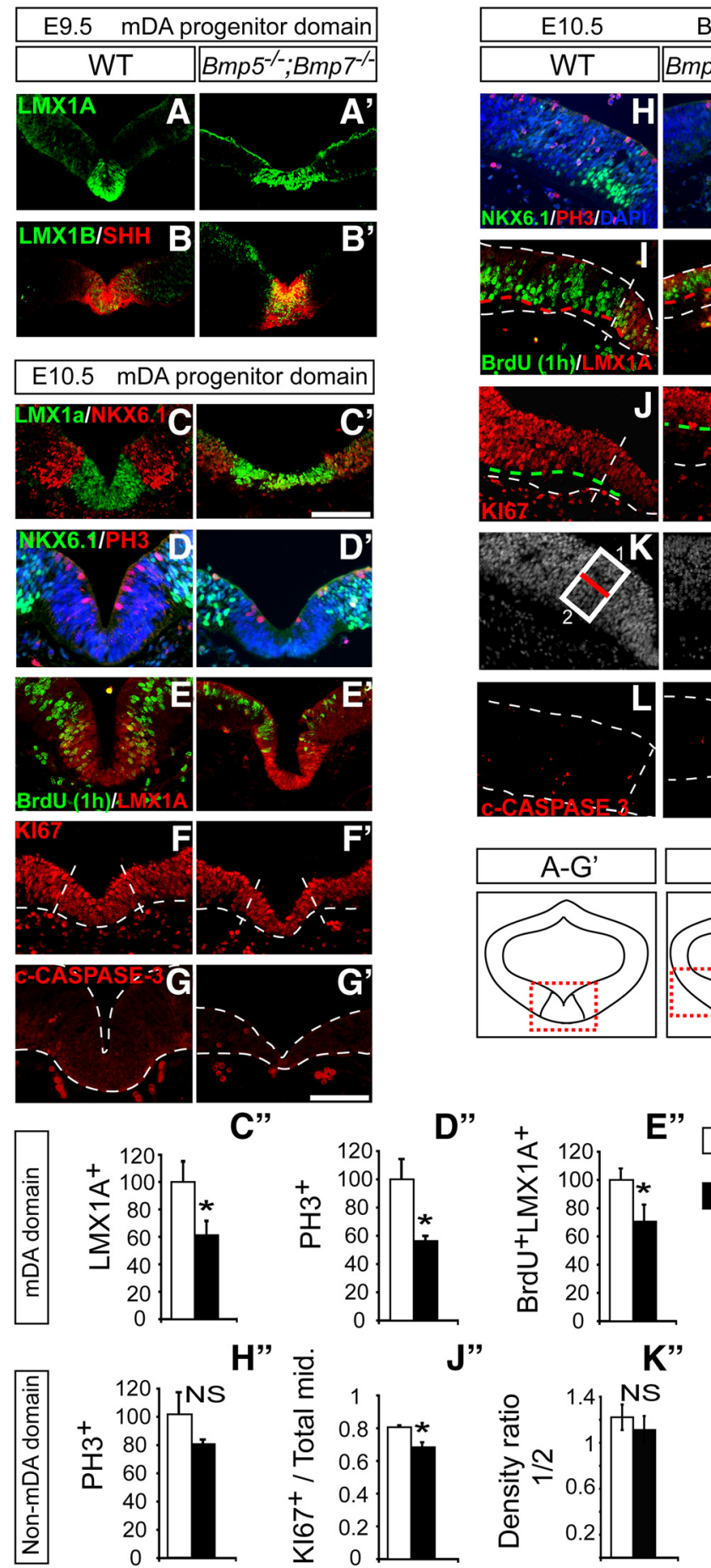

Figure 2. BMP5/7 promote proliferation of $\mathrm{mDA}$ progenitors. The ventral midbrain of $\mathrm{E} 9.5 \mathrm{Bmp5^{-/- }} ; \mathrm{Bmp} 7^{-/-}$mutants show normal patterning of the mDA progenitor domain as visualized by LMX1A, LMX1B, and SHH expression $\left(\boldsymbol{A}-\boldsymbol{B}^{\prime}\right)$. At E10.5, the boundary relationship between the $\mathrm{mDA}$ progenitor domain (LMX1A ${ }^{+}$cells) and the adjacent red nucleus progenitor domain (NKX6.1 ${ }^{+}$cells) does not differ between the phenotypes $\left(\boldsymbol{C}, \boldsymbol{C}^{\prime}\right)$. Quantification of LMX1A ${ }^{+}$mDA progenitors at E10.5 indicates a significant reduction in Bmp5 $5^{-1-} ; B m p 7^{-1-}$ mutants $\left(\boldsymbol{C}^{\prime \prime}\right)$. Phosphorylated-histone $\mathrm{H3}$ (PH3)-positive mitotic cells in the mDA domain bordered by NKX6.1 expression were significantly reduced in Bmp5 $5^{-1-} ; B m p 7^{-/-}$mutants $\left(\boldsymbol{D}-\boldsymbol{D}^{\prime \prime}\right)$. The number of BrdU-immunoreactive cells after $1 \mathrm{~h}$ short pulse incorporation coexpressing $\mathrm{LMX} 1 \mathrm{~A}\left(\boldsymbol{E}-\boldsymbol{E}^{\prime \prime}\right)$ and $\mathrm{KI}_{67}{ }^{+}\left(\boldsymbol{F}, \boldsymbol{F}^{\prime}\right)$ were decreased in the mDA progenitor domain of Bmp5 $5^{-1-} ; B m p 7^{-1-}$ mutants. In contrast, cleaved caspase-3 (c-caspase3) immunoreactivity visualizing apoptotic nuclei did not show any obvious differences between genotypes $\left(\mathbf{G}, \mathbf{G}^{\prime}\right)$. In the midbrain of E10.5 $B m p 5^{-1-} ; B m p 7^{-1-}$ mutants outside of the $\mathrm{mDA}$ progenitor domain, the number of $\mathrm{PH} 3^{+}$cells showed a trend in reduction, which did not, however, reach statistical significance $\left(\boldsymbol{H}-\boldsymbol{H}^{\prime \prime}\right)$. BrdU ${ }^{+}$cell nuclei after $1 \mathrm{~h}$ short pulse incorporation accumulated in the ventricular zone of $B m p 5^{-I-} ; B m p 7^{-I-}$ mutants $\left(I, I^{\prime}\right)$. Similar to BrdU ${ }^{+}$cells, dividing $\mathrm{KI}_{67^{+}}$cells were also found predominantly in the ventricular side of the neural tube and the ratio of the midbrain area covered by the cells and total midbrain area was significantly reduced $\left(\boldsymbol{J}-\boldsymbol{J}^{\prime \prime}\right)$. Densities of DAPI ${ }^{+}$cell nuclei did not differ between the ventricular zone and mantle zone of the neural tube $\left(\boldsymbol{K}-\boldsymbol{K}^{\prime \prime}\right)$. Cleaved caspase-3 immunoreactivity in the midbrain outside of the mDA progenitor domain did not mutants showed a $43 \%$ reduction in postmitotic $\mathrm{MAP}-2^{+}$neurons in the $\mathrm{mDA}$ progenitor domain again following normalization to the number of $\mathrm{LMX}^{+} \mathrm{A}^{+}$cells (Fig. 3C-C'; $\left.t_{(4)}=3.19,{ }^{*} p=0.033\right)$.

In contrast, outside of the mDA progenitor domain, $B m p 5^{-I-} ; B m p 7^{-I-}$ mutants exhibited an increase of $10 \%$ in the area containing $\mathrm{MAP}-2^{+}$postmitotic neurons (Fig. $3 E-E^{\prime \prime} ; t_{(4)}=-3.98,{ }^{* *} p=$ $0.01)$. An apparent increase in the number of $\mathrm{NGN}_{2}{ }^{+}$and NKX6.1 ${ }^{+}$cells that did not reach statistical significance was also observed (Fig. 3D-D", $t_{(4)}=1.85, p=$ 0.14 ; Fig. $\left.3 F-F^{\prime \prime}, t_{(4)}=1.67, p=0.17\right)$. We conclude that $\mathrm{BMP} 5 / 7$ promote $\mathrm{mDA}$ neurogenesis by regulating MSX1/2 and NGN2 expression. In contrast, BMP5/7 appear to prevent premature neurogenesis in the midbrain basal plate outside of the MSX1/2-positive mDA progenitor domain.

BMP5/7 repress SHH expression in the floor plate

Next, we studied the interaction of BMP5/7 with the WNT and SHH pathways, which both play a key role in $\mathrm{mDA}$ formation, by visualizing the expression of WNT and $\mathrm{SHH}$ signaling components in $B m p 5^{-1-} ; B m p 7^{-1-}$ mutants. Although WNT signaling promotes the formation of $\mathrm{mDA}$ neurons throughout embryogenesis (Prakash et al., 2006; Andersson et al., 2013), SHH is necessary for early steps of mDA progenitor induction (Ye et al., 1998), but was suggested to repress $\mathrm{mDA}$ neurogenesis at later stages (Joksimovic et al., 2009). Neither Wnt1 mRNA expression (Fig. $4 A, A^{\prime}$ ) nor total $\beta$-catenin immunofluorescence signal strength (Fig. $4 B-B^{\prime}, t_{(2)}=-0.07, p=$ 0.95; see Fig. $4 C, C^{\prime}$ for higher magnification), which plays a critical role in mediating canonical WNT signaling, was altered in $B m p 5^{-1-} ; B m p 7^{-1-}$ mutants. Furthermore, cell adhesion, which is dependent on intact $\beta$-catenin in the $\mathrm{mDA}$ progenitor domain (Tang et al., 2009; Chilov et al., 2011), was unperturbed in the mutants, as assessed by the normal expression of $\mathrm{N}$-cadherin and ZO-1 (Fig. $\left.4 D-E^{\prime}\right)$. The number of cell nuclei with accumulation of the GSK3- $\beta$ phosphorylated (S33/S37/Th41) $\beta$-catenin form, marked for degradation, was reduced by

$$
\leftarrow
$$

show any differences between genotypes $\left(\boldsymbol{L}, \boldsymbol{L}^{\prime}\right)$. Two tailed unpaired Student, $t$ test ${ }^{*} p<0.05$. Scale bars: $A-C, 100 \mu \mathrm{m}$; $D-L^{\prime}, 50 \mu \mathrm{m}$. 

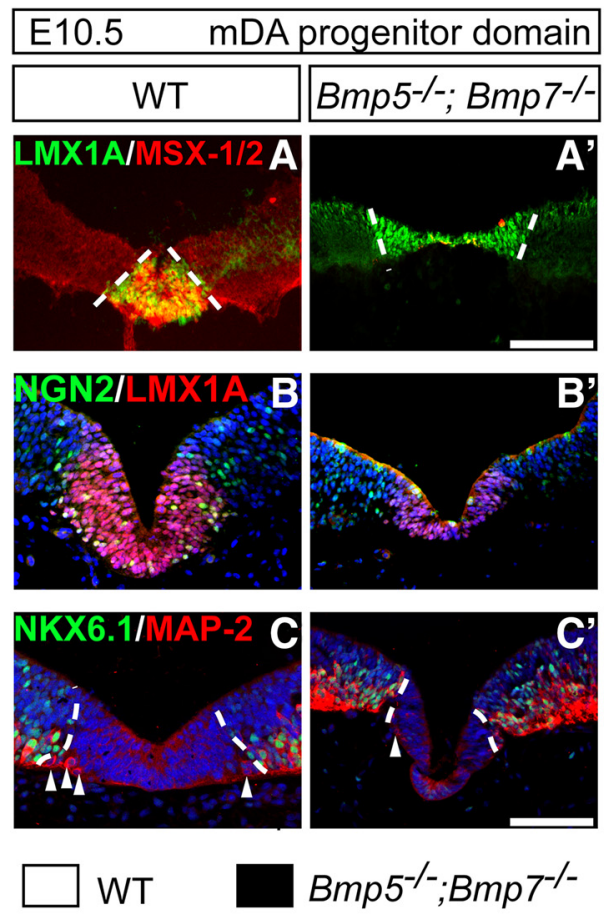
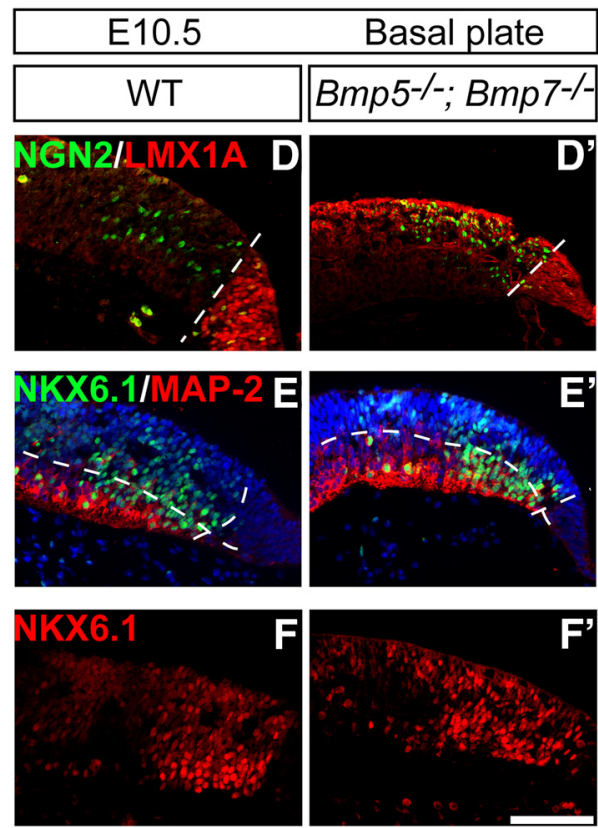
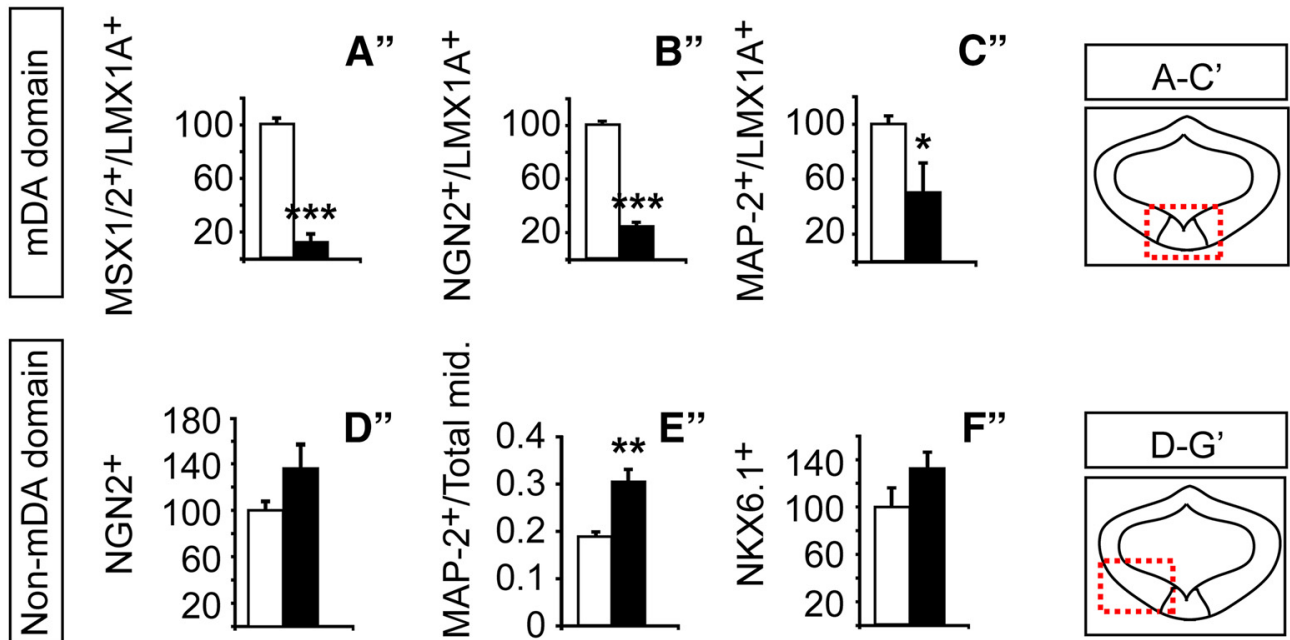

Figure 3. BMP5/7 are required for the induction of mDA neurogenesis. The number of MSX-1/2 ${ }^{+} \mathrm{NGN2}{ }^{+}$and postmitotic MAP- $2^{+}$cells in the LMX1A ${ }^{+}$region were significantly reduced in $B m p 5^{-1-} ; B m p 7^{-I-}$ mutants even after normalization to the reduced number of $\mathrm{LMX} 1 \mathrm{~A}^{+}$cells $\left(\boldsymbol{A}-\boldsymbol{C}^{\prime \prime}\right)$. The number of NGN2 ${ }^{+}$cells in the midbrain of $B m p 5^{-I-} ; B m p 7^{-I-}$ mutants outside of the mDA progenitor domain was not reduced $\left(\boldsymbol{D}-\boldsymbol{D}^{\prime \prime}\right)$ and the area covered by MAP- $2^{+}$neurons compared with the total midbrain area showed an increase $\left(\boldsymbol{E}-\boldsymbol{E}^{\prime \prime}\right)$. The number of NKX6.1 ${ }^{+}$cells did not show a decrease, but rather a trend toward an increase in the midbrain of $B \mathrm{mp} 5^{-I-} ; B \mathrm{Bmp} 7^{-I-}$ mutants outside of the mDA progenitor domain. Two tailed unpaired Student, $t$ test ${ }^{*} p<0.05$, ${ }^{* *} p<$ $0.01,{ }^{* * *} p<0.001$. Scale bars, $\boldsymbol{A}, \boldsymbol{A}^{\prime}, 100 \mu \mathrm{m} ; \boldsymbol{B}-\boldsymbol{F}^{\prime}, 50 \mu \mathrm{m}$.

$60.7 \%$ in the $\mathrm{mDA}$ progenitor domain of $B m p 5^{-1-} ; B m p 7^{-1-}$ mutants after normalization to the number of $\mathrm{LMX1A}^{+}$cells (Fig. $4 F-F^{\prime \prime}, t_{(2)}=5.325,{ }^{\star} p=0.033$ ). To further study WNT/ $\beta$ catenin signaling, we analyzed the expression of its direct downstream target cyclin D1 (CCND1). CCND1 at E10.5 showed strong ubiquitous expression throughout the midbrain in both genotypes (Fig. $4 G, G^{\prime}$ ), with the exception of the $\mathrm{LMX1A}^{+} \mathrm{mDA}$ domain (Fig. $4 G^{\prime \prime}-G^{\prime \prime \prime}$ ). Together, our results suggest that WNT/ $\beta$-catenin signaling was not reduced in $B m p 5^{-I-} ; B m p 7^{-I-} \mathrm{mu}-$ tants. In contrast, the signal intensity of $\mathrm{SHH}$ immunoreactivity, measured as a ratio of SHH signal between the midline (box 1) and a region outside of $\mathrm{SHH}$ expression domain (box 2), was nearly doubled in $B m p 5^{-I-} ; B m p 7^{-1-}$ mutants (Fig. $4 H-I^{\prime \prime} ; t_{(4)}=$ $\left.3.186,{ }^{*} p=0.03\right)$.
To study which intracellular molecules mediate the effects of BMPs in the formation of $\mathrm{mDA}$ neurons, we visualized the canonical BMP signaling components p-SMAD-1/5/8. Compared with WT, $B m p 5^{-1-} ; B m p 7^{-1-}$ mutants exhibited a $45 \%$ reduction in the number of p-SMAD-1/5/8-immunoreactive cells after normalization to the number of LMX1A ${ }^{+}$cells (Fig. $4 J-J^{\prime \prime}, t_{(4)}=$ $\left.4.66,{ }^{* * *} p=0.0096\right)$. This suggests that SMAD- $1 / 5 / 8$ mediate the loss of mDA postmitotic neurons in mutants. Because BMP receptors can also initiate the activation of non-Smad signaling pathways, mostly by MAP kinases (Mueller and Nickel, 2012), we studied the expression of p-ERK, p-JNK, and p-P38 in the ventral midbrain of mutants. In contrast to p-ERK and p-JNK, which were not detected in the $\mathrm{mDA}$ progenitor domain at E10.5 (data not shown), p-P38 was strongly expressed there but did not show 

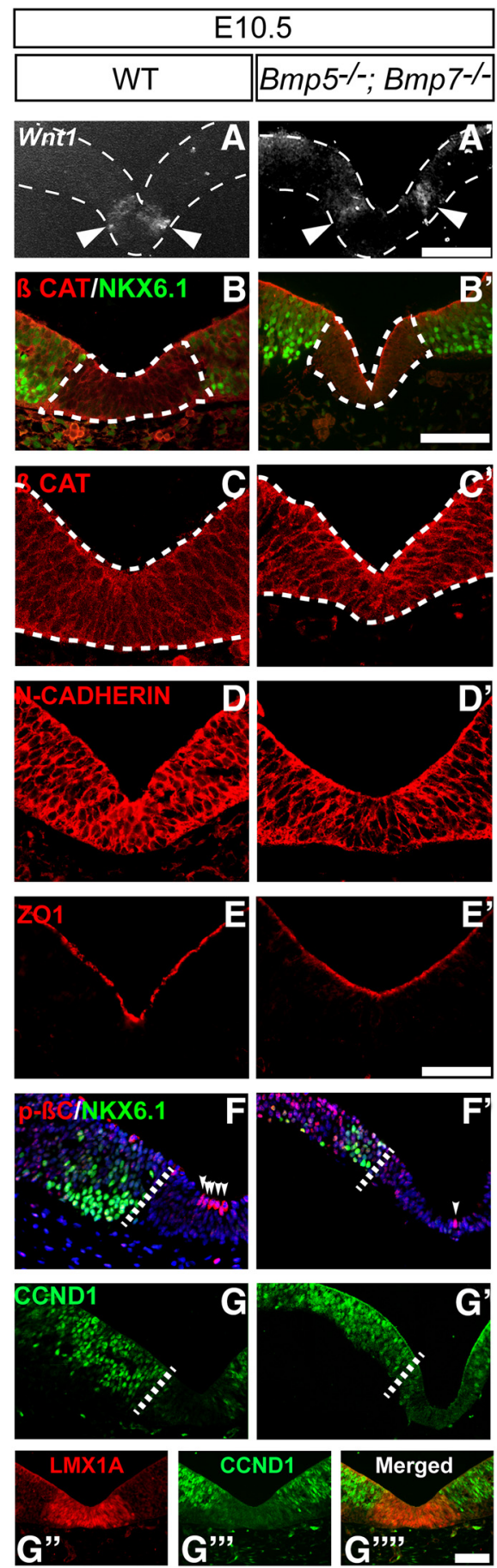
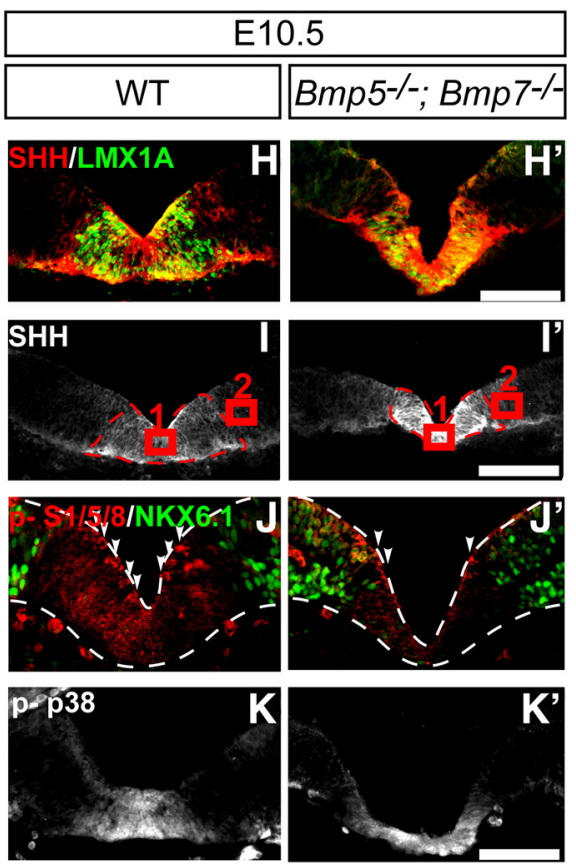

$\square$ WT

$\mathrm{Bmp5}^{-/-} ; \mathrm{Bmp} 7^{-/-}$

B"
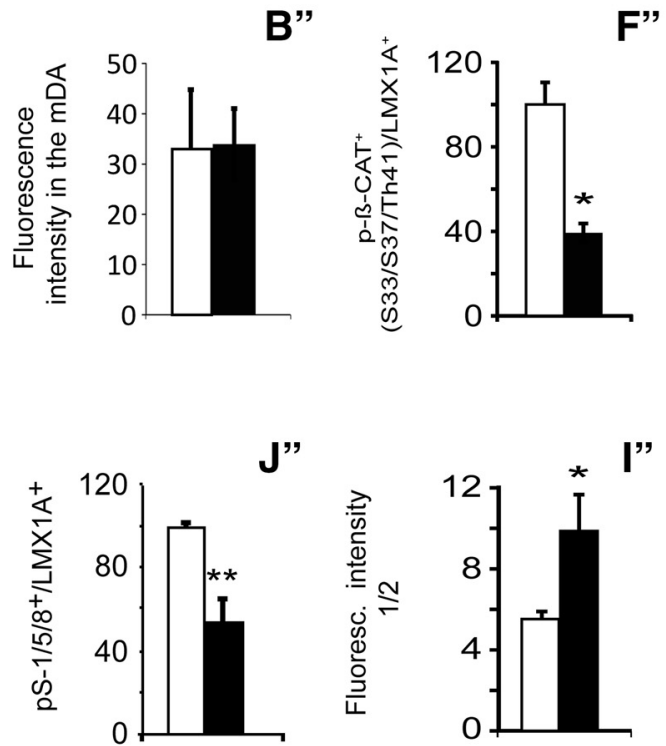

Figure 4. BMP5/7 repress SHH expression in the medial floor plate. Wnt1 mRNA intensity in Bmp5 $5^{-1-} ; B m p 7^{-1-}$ mutants is comparable to WT $\left(\boldsymbol{A}, \boldsymbol{A}^{\prime}\right)$. The expression level measured by fluorescence intensity in the mDA domain $\left(\boldsymbol{B}^{\prime \prime}\right)$ and the distribution of BETA-CATENIN $\left(\boldsymbol{B}-\boldsymbol{C}^{\prime}\right)$, an essential component of the canonical WNT signaling pathway, were unaltered between genotypes. The cell to cell adhesion marker N-CADHERIN and immunoreactivity of the tight junction protein Z01 also do not show any differences in expression levels or distribution between genotypes ( $\boldsymbol{D}-\boldsymbol{E}^{\prime}$ ). S33/S37/Th41 phosphorylated beta-CATENIN form was significantly reduced in in $B m p 5^{-/-} ; B m p 7^{-1-}$ mutants $\left(\boldsymbol{F}-\boldsymbol{F}^{\prime \prime}\right)$, while CCND1 was expressed in the midbrain, but not in the $\mathrm{mDA}$ domain in WTs $\left(\boldsymbol{G}, \boldsymbol{G}^{\prime \prime}-\boldsymbol{G}^{\prime \prime \prime}\right)$ nor in mutants $\left(\boldsymbol{G}^{\prime}\right)$. SHH expression levels are increased in the LMX1A ${ }^{+}$mDA progenitor domain in $B m p 5^{-/-} ; B m p 7^{-/-}$mutants $\left(\boldsymbol{H}, \boldsymbol{H}^{\prime}\right)$. SHH total fluorescence signal intensity was quantified by dividing ventral midline signal (1) by the signal intensity in the region directly outside of the SHH expression domain (2) (I-I'). The number of PHOSPHO-SMAD-1/5/8 ${ }^{+}$ cells in the mDA progenitor domain (arrowheads) was reduced in $B m p 5^{-/-} ; B m p 7^{-1-}$ mutants, even after normalization to the reduction number of $L_{M X 1 A}{ }^{+}$cells $\left(J-J^{\prime \prime}\right)$. Expression of the activated MAP kinase P-38 (PHOSPHO-P38) in the mDA domain did not show any differences between genotypes $\left(\boldsymbol{K}-\boldsymbol{K}^{\prime}\right.$ ). Two tailed unpaired Student, $t$ test ${ }^{*} p<0.05,{ }^{* *} p<0.01$. Scale bars: $\boldsymbol{A}$, $', I, I^{\prime}, E-F^{\prime}, 100 \mu \mathrm{m} ; \boldsymbol{B}, \boldsymbol{B}^{\prime}, \boldsymbol{F}-\boldsymbol{G}^{\prime}, \boldsymbol{J}-\boldsymbol{K}^{\prime}, 50 \mu \mathrm{m} ; \boldsymbol{C}-\boldsymbol{E}^{\prime}, \boldsymbol{G}^{\prime \prime}-\boldsymbol{G}^{\prime \prime \prime \prime}, 25 \mu \mathrm{m}$.

any differences in expression compared with WT (Fig. $4 K, K^{\prime}$ ). Together, our data suggest that one of the functions of BMP5/7 in the development of $\mathrm{mDA}$ neurons is to provide a permissive environment for $\mathrm{mDA}$ neurogenesis by repression of $\mathrm{SHH}$ expression in the midbrain floor plate.
SMAD1 is necessary for the formation of $\mathrm{mDA}$ neurons Based on the lack of postmitotic mDA neurons (Fig. $1 \mathrm{~N}-\mathrm{O}^{\prime \prime}$ ) and the downregulation of p-SMAD1/5/8 (Fig. 4J-J') in $B m p 5^{-1-}$; $B m p 7^{-1-}$ mutants, we hypothesized that components of the SMAD signaling pathway are mediating aspects of the effect of 

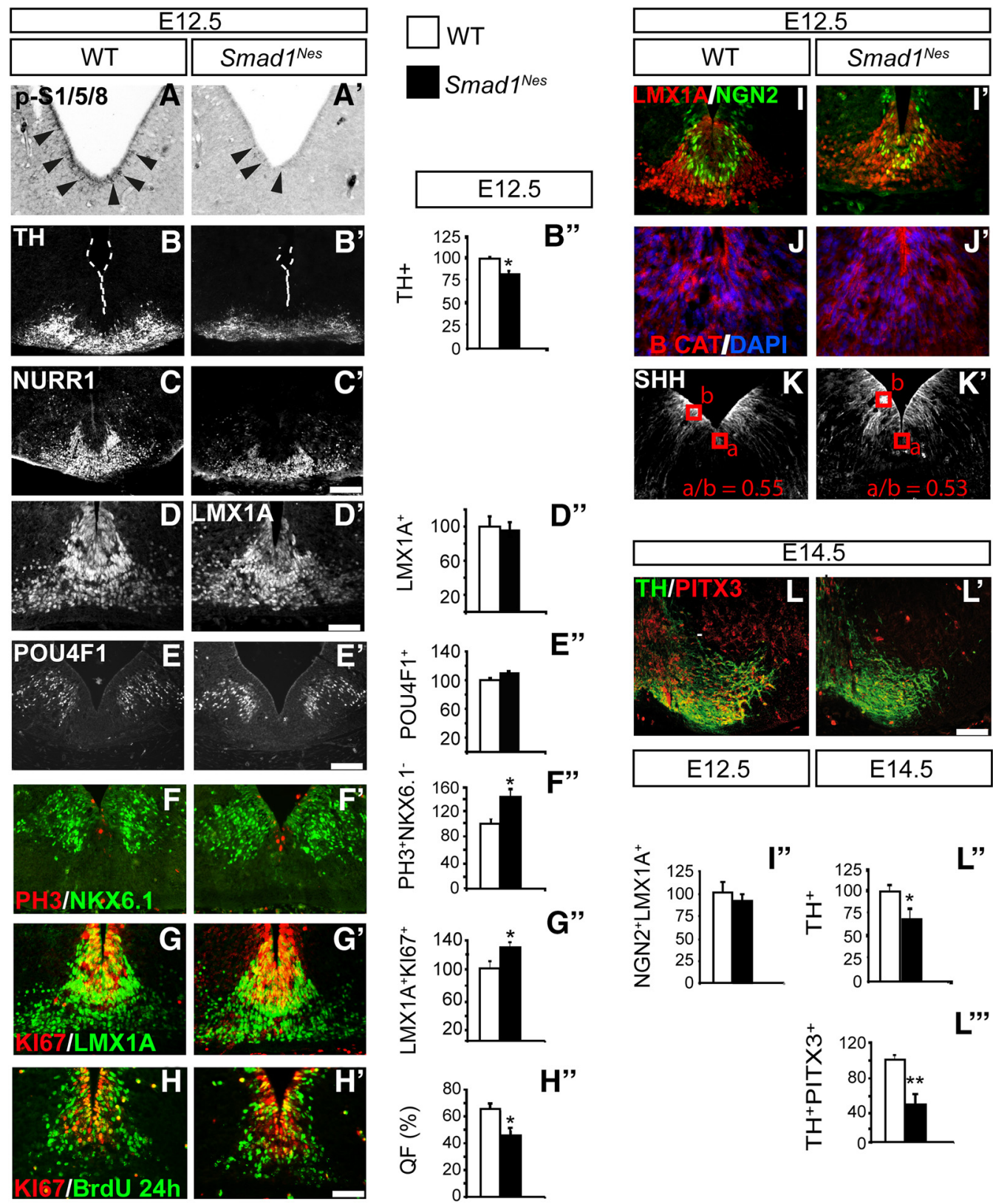

Figure 5. SMAD1 is necessary for the formation of mDA neurons. Representative midbrain coronal sections of WT and Smad $1{ }^{\text {Nes }}$ mutant littermates at E12.5 and E14.5. phospho-SMAD-1/5/8positive cells (arrowheads) are strongly reduced in Smad $1^{\text {Nes }}$ mutants $\left(\boldsymbol{A}, \boldsymbol{A}^{\prime}\right)$. Midbrain $\mathrm{TH}^{+}$neurons are significantly reduced in Smad ${ }^{\text {Nes }}$ mutants $\left(\boldsymbol{B}-\boldsymbol{B}^{\prime \prime}\right)$. NURR1 postmitotic neurons appear reduced in Smad $1^{\text {Nes }}$ mutants $\left(\boldsymbol{C}, \boldsymbol{C}^{\prime}\right)$, while the numbers of LMX1a ${ }^{+}$mDA progenitors $\left(\boldsymbol{D}-\boldsymbol{D}^{\prime \prime}\right)$ and P0U1F4 ${ }^{+}$red nucleus progenitors $\left(\boldsymbol{E}-\boldsymbol{E}^{\prime \prime}\right)$ show no statistical changes between phenotypes. In $\mathrm{mDA}$ progenitor domain of Smad1 ${ }^{\text {Nes }}$ mutants, the number of $\mathrm{PH}^{+}{ }^{+}$mitotic cells flanked by NKX6.1 expression $\left(\boldsymbol{F}-\boldsymbol{F}^{\prime \prime}\right)$ and $\mathrm{LMX}^{+} \mathrm{A}^{+} \mathrm{KI} 7^{+}$cells $\left(\boldsymbol{G}-\boldsymbol{G}^{\prime \prime}\right)$ are significantly increased. The quitting

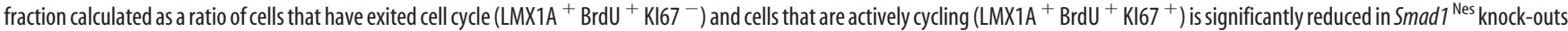
$\left(\boldsymbol{H}-\boldsymbol{H}^{\prime \prime}\right)$. There is no difference in the numbers of LMX1A ${ }^{+} \mathrm{NGN2}{ }^{+}$cells between genotypes $\left(\boldsymbol{I}-\boldsymbol{I}^{\prime \prime}\right)$. In Smad $7^{\text {Nes }}$ mutants, BETA-catenin is normally expressed $\left(\boldsymbol{J}-\boldsymbol{J}^{\prime}\right)$. SHH has retracted in both WT and mutants from the midline at this developmental stage, as measured by comparing the signal intensity of the midline to the adjacent basal plate $\left(\boldsymbol{K}-\boldsymbol{K}^{\prime}\right)$. Also at E14.5, the number of TH ${ }^{+}$cells is decreased in Smad $1{ }^{\text {Nes }}$ mutants. The reduction in $\mathrm{TH}^{+}{ }^{+}$PITX ${ }^{+}$cells exceeds the reduction observed in $\mathrm{TH}^{+}$cells $\left(\boldsymbol{L}-\boldsymbol{L}^{\prime \prime \prime}\right)$. Two tailed unpaired Student, $t$ test ${ }^{*} p<0.05,{ }^{* *} p<0.01$. Scale bars: $\boldsymbol{B}-\boldsymbol{C}^{\prime}, \boldsymbol{E}$, $\boldsymbol{E}^{\prime}, 100 \mu \mathrm{m} ; \boldsymbol{A}, \boldsymbol{A}^{\prime}, \boldsymbol{D}-\boldsymbol{D}^{\prime}, \boldsymbol{F}-\boldsymbol{I}^{\prime}, 50 \mu \mathrm{m} ; \boldsymbol{J}, \boldsymbol{J}^{\prime}, 25 \mu \mathrm{m}$.

BMP5/7 on mDA neuron formation. To test this hypothesis, we assessed the formation of mDA neurons in mutants in which Smad1 was conditionally inactivated using a Nestin-Cre driver $\left(\right.$ Smad1 ${ }^{\mathrm{Nes}}$ ) (Tronche et al., 1999). Because, in these mutants, Cre activity starts to get activated in the ventral midbrain between E10.5 and E11.5 (Vernay et al., 2005), we were able to assess the role of the BMP/SMAD pathway at developmental time points later than in $B m p 5^{-/-} ; B m p 7^{-/-}$mutants.

In $S m a d 1^{\text {Nes }}$ mutants at E12.5, p-SMAD1/5/8 immunoreactivity was profoundly reduced (Fig. $5 A, A^{\prime}$ ). Concomitantly, the number of $\mathrm{TH}^{+}$cells was significantly decreased by $19 \%$ at E12.5 compared with WT littermates (Fig. $5 B-B^{\prime \prime} ; t_{(10)}=2.473,{ }^{\star} p=$ $\left.0.0329, n=6 \mathrm{WT} ; n=6 \mathrm{Smad}^{\mathrm{Nes}}\right)$ and NURR1 ${ }^{+}$cells also appeared reduced (Fig. $5 C, C^{\prime}$ ). The total number of $\mathrm{LMX} \mathrm{A}^{+}$ cells did not differ significantly between the genotypes at this time point (Fig. $5 D-D^{\prime \prime}, t_{(2)}=-0.23, p=0.83, n=4 \mathrm{WT} ; n=4$ Smad $\left.1^{\text {Nes }}\right)$. The red nucleus, as visualized by POU4F1, was normal in Smad1 mutants (Fig. $5 E-E^{\prime \prime} ; t_{(4)}=1.35, p=0.25$ ). To quantify the total number of cells undergoing mitosis, we counted $\mathrm{PH}^{+}$cells in the mDA progenitor domain laterally 

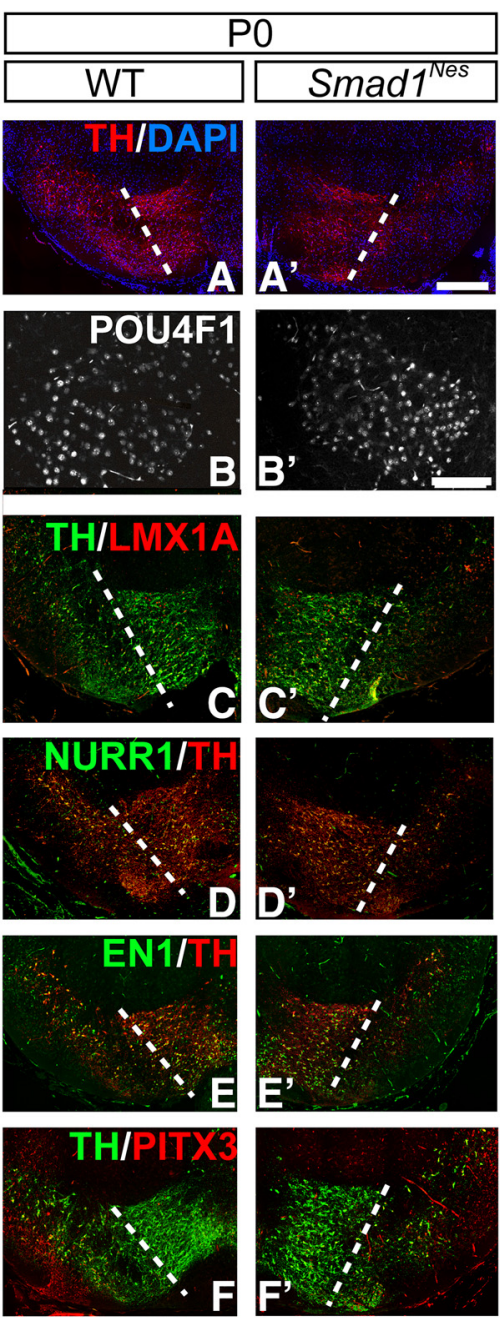

$\square$ WT
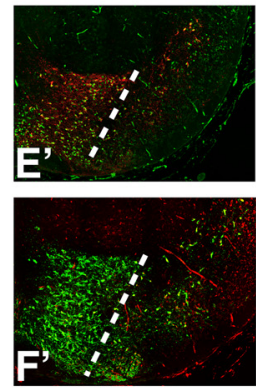

Smad1 $1^{\text {Nes }}$
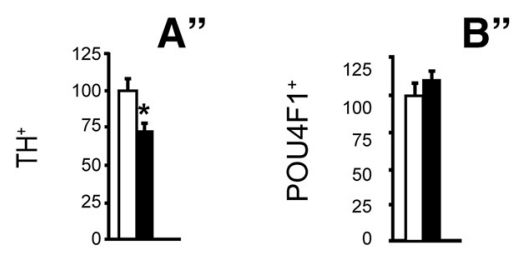

B”
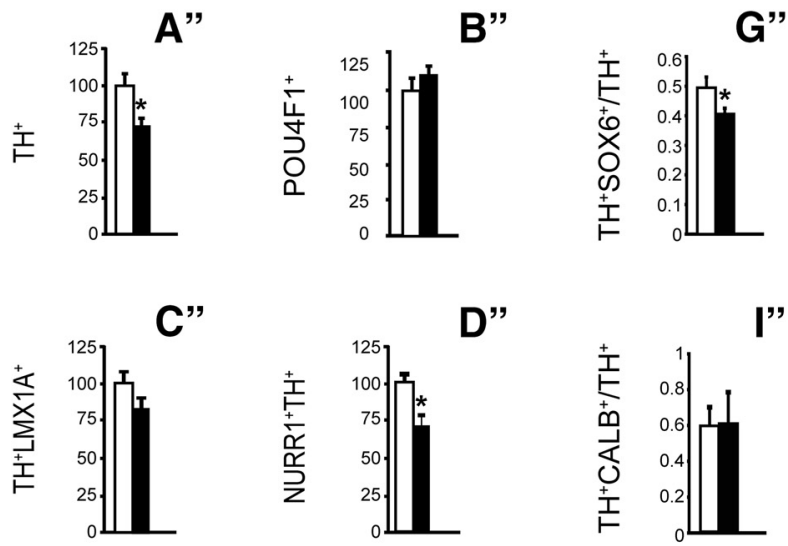

D"
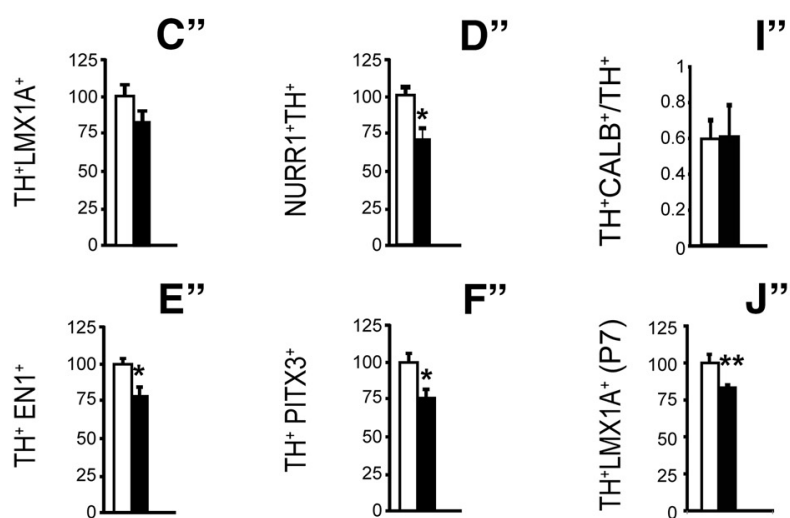
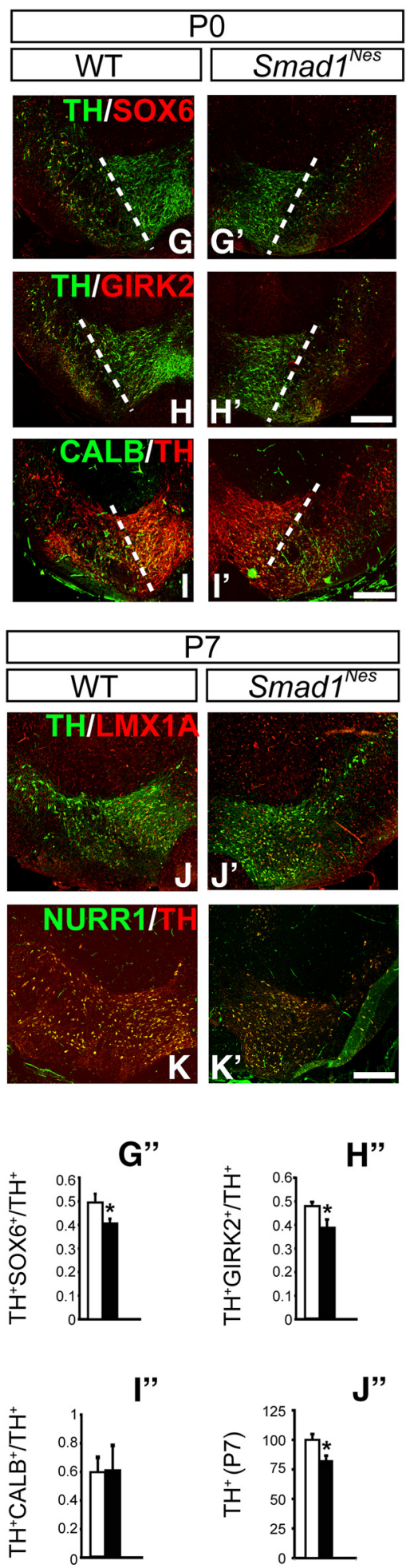

"
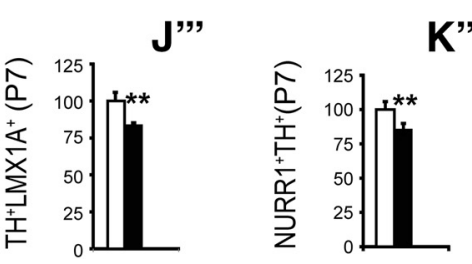

flanked by NKX6.1 ${ }^{+}$cells. The Smad 1 inactivation strongly increased the number of dividing cells in this domain by $42 \%$ (Fig. $5 F-F^{\prime \prime} ; t_{(6)}=3.05,{ }^{*} p=0.022, n=4$ number of mDA progenitors in the active cell cycle $\left(\mathrm{LMX1A}^{+} \mathrm{Ki}^{+} 7^{+}\right)$was increased by $29 \%$ (Fig. $5 G-G^{\prime \prime} ; t_{(5)}=-2.622,{ }^{*} p=$ $0.046, n=3 \mathrm{WT} ; n=4$ Smad1 $\left.^{\text {Nes }}\right)$. To investigate whether the decrease of $\mathrm{mDA}$ neurons could be caused by a reduced number of $\mathrm{mDA}$ progenitors exiting the cell cycle, we assessed the quitting fraction, calculated as the percentage of cycling progenitors exiting the cell cycle within $24 \mathrm{~h}$ of BrdU administration at E11.5. To do so, we measured the fraction of ${\mathrm{LMX} 1 \mathrm{~A}^{+} \mathrm{BrdU}}^{+}$cells that were that the quitting fraction decreased significantly from an average of $66 \%$ in WT to an average of $44 \%$ in Smad $1^{\mathrm{Nes}}$ conditional mutant embryos (Fig. $5 \mathrm{H}-\mathrm{H}^{\prime \prime}$; $t_{(5)}=2.6,{ }^{*} p=0.048, n=3 \mathrm{WT} ; n=4$ $\left.S m a d 1^{\text {Nes }}\right)$. In contrast, the number of $\mathrm{LMX} 1 \mathrm{~A}^{+} \mathrm{NGN2}{ }^{+}$cells was not changed between genotypes (Fig. $5 I-I^{\prime \prime} ; t_{(6)}=$ 1.176, $p=0.28, n=4 \mathrm{WT} ; n=4$ $\left.S m a d 1^{\text {Nes }}\right)$. The unaltered expression of $\beta$-catenin in $B m p 5^{-1-} ; B m p 7^{-1-} \mathrm{mu}-$ tants indicated normal canonical WNT signaling in these animals (Fig. $5 \mathrm{~J}, \mathrm{~J}^{\prime}$ ). Moreover, SHH expression, which has retracted from the midline at this developmental stage, showed no changes between genotypes (Fig. $5 K, K^{\prime} ; \mathrm{WTa} / \mathrm{b}=$ $0.55 \pm 0.06$, Smad $^{\mathrm{Nes}} \mathrm{a} / \mathrm{b}=0.53 \pm$ $\left.0.09, t_{(4)}=-0.719, p=0.51\right)$.

Also at E14.5, the number of $\mathrm{TH}^{+}$cells was reduced in Smad1 ${ }^{\text {Nes }}$ mutants by $25 \%$ (Fig. $5 L-L^{\prime \prime}, t_{(4)}=3.65,{ }^{*} p=0.02$ ). Interestingly, Smad ${ }^{\text {Nes }}$ mutants showed an even stronger reduction in the number of $\mathrm{TH}^{+}$PITX $^{+}{ }^{+}$neurons at E14.5 of $\sim 50 \%$ (Fig. $5 L-L^{\prime}, L^{\prime \prime \prime} ; t_{(4)}=9.09,{ }^{* *} p=$ $0.00812)$. In summary, our data indicate that, after E10.5, SMAD1-mediated BMP signaling regulates neurogenesis of $\mathrm{mDA}$ neurons by promoting the cell cycle exit of mDA progenitors. WT; $n=4$ Smadl $^{\text {Nes }}$ ). In addition, the immunonegative for Ki67. We found

Figure 6. In postnatal POSmad $7^{\text {Nes }}$ mutants $\mathrm{TH}^{+} \mathrm{SOX6} 6{ }^{+}$and $\mathrm{TH}^{+} \mathrm{GIRK2}{ }^{+} \mathrm{SN}$ neurons are more affected than $\mathrm{TH}^{+} \mathrm{CALB}^{+}$ VTA neurons. Coronal sections of WT and $S m a d 7^{\text {Nes }}$ midbrains at $\mathrm{PO}$ and $\mathrm{P7}$ are represented. The number of $\mathrm{TH}^{+}{ }^{+}$cells is significantly reduced in Smad $7^{\text {Nes }}$ mutants $\left(\boldsymbol{A}-\boldsymbol{A}^{\prime \prime}\right)$. The red nucleus visualized by POU4F1 expression does not show differences beetwen the

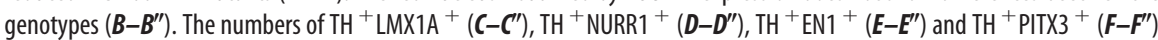

\footnotetext{
neurons were significantly reduced in $S \mathrm{mad} 7^{\text {Nes }}$ mutants. The percentages of $\mathrm{TH}^{+} \mathrm{SOXK}^{+}\left(\mathbf{G}-\mathbf{G}^{\prime \prime}\right)$ and $\mathrm{TH}^{+} \mathrm{GIRK}^{+}\left(\mathrm{H}_{-}\right.$ $\left.\boldsymbol{H}^{\prime \prime}\right)$ SN neurons of the total midbrain $\mathrm{TH}^{+}$neurons were reduced in $\mathrm{Smad}^{\mathrm{Nes}}$ mutants. Conversely, the $\mathrm{TH}^{+} \mathrm{CALB}^{+}$ portion of the total $\mathrm{TH}^{+}$neurons did not show difference beetwen the genotypes $\left(I-I^{\prime \prime}\right)$. Additionaly, $\mathrm{TH}^{+}$neurons $(J-$ $\left.J^{\prime \prime}\right)$ as well as $\mathrm{TH}^{+} \mathrm{LMX1A}^{+}\left(J, J^{\prime}, J^{\prime \prime \prime}\right)$ and TH ${ }^{+}$NURR1 ${ }^{+}$ $\left(\boldsymbol{K}-\boldsymbol{K}^{\prime \prime}\right)$ neurons showed significant reduction in $S \mathrm{mad} 7^{\text {Nes }}$ mutants at P7. Two tailed unpaired Student, $t$ test ${ }^{*} p<0.05$, ${ }^{* *} p<0.01$. Scale bars: $\boldsymbol{A}, \boldsymbol{A}^{\prime}, \boldsymbol{C}-\boldsymbol{H}^{\prime}, \boldsymbol{J}-\boldsymbol{K}^{\prime}, 100 \mu \mathrm{m} ; \boldsymbol{I}, \boldsymbol{I}^{\prime}, 75$ $\mu \mathrm{m} ; \boldsymbol{B}, \boldsymbol{B}^{\prime}, 25 \mu \mathrm{m}$.
} 
A

D 0

D 8

D 30

Fibroblast $\Longrightarrow$ iPSC $\rightleftarrows$ NSC
Fibroblast $\rightleftarrows$ iNSC

Start of diff.

Maturation

BMP5 and BMP7

Analysis

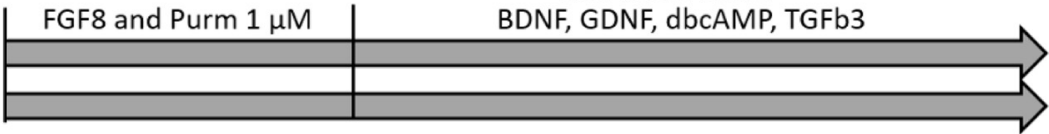

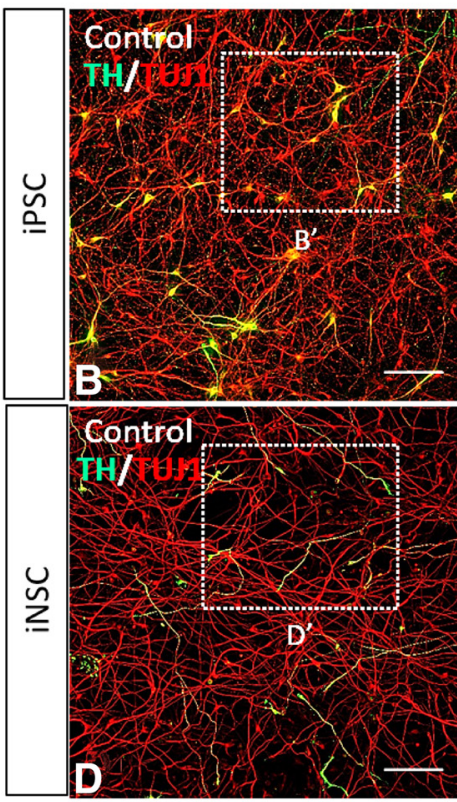
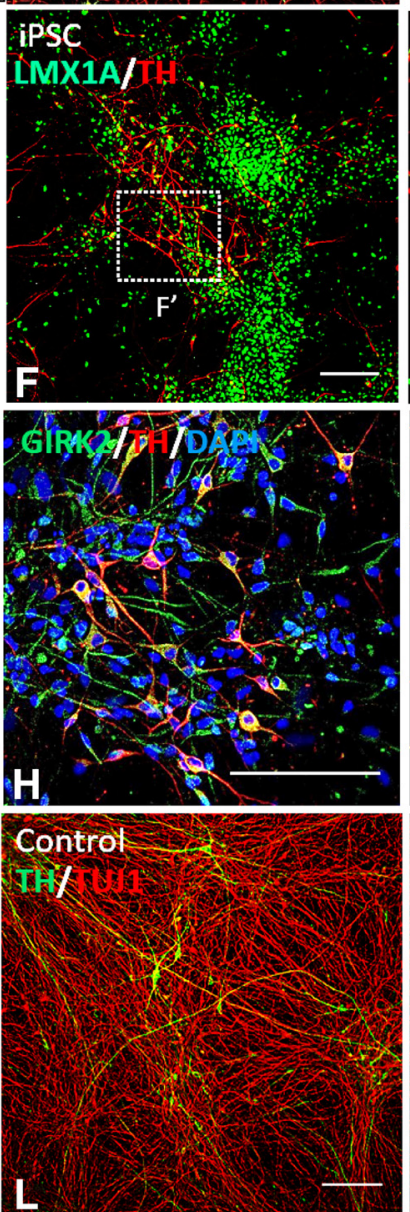
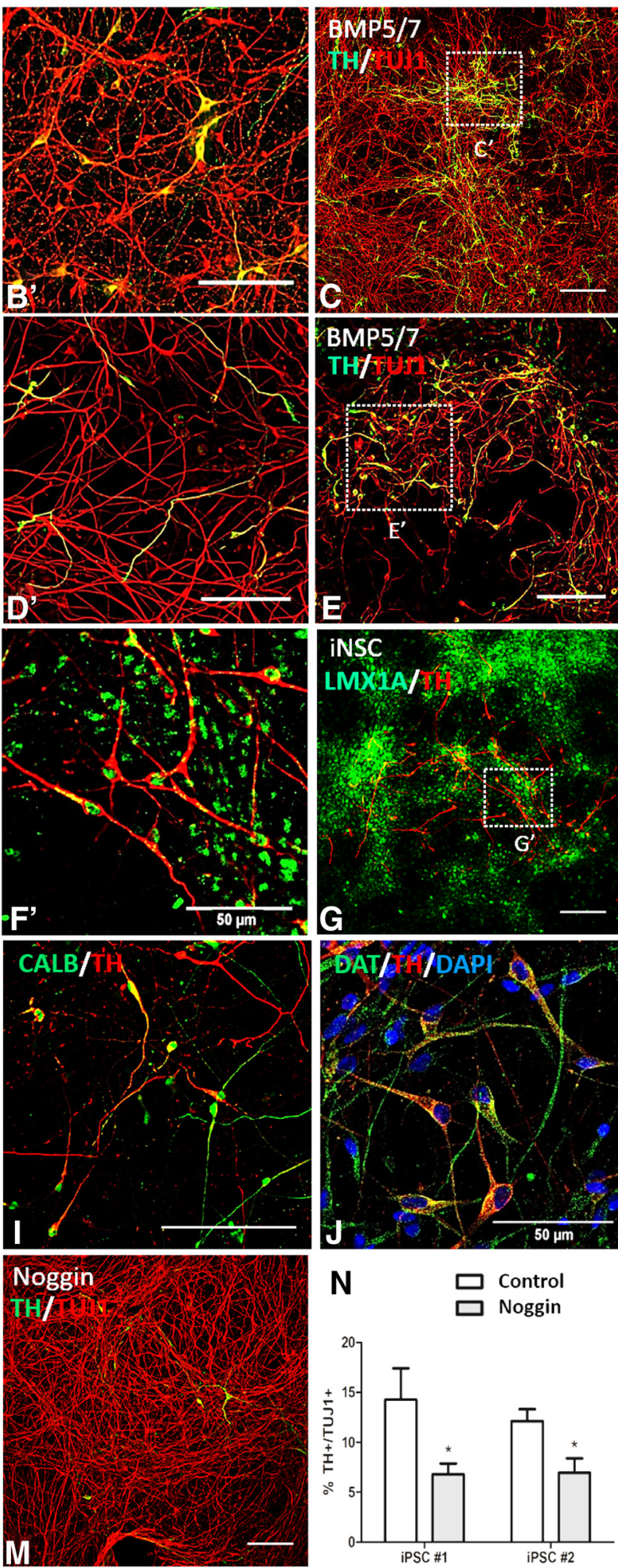

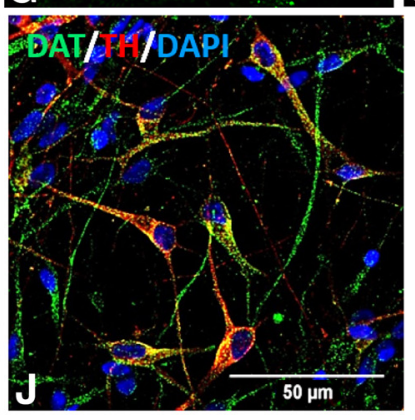

N
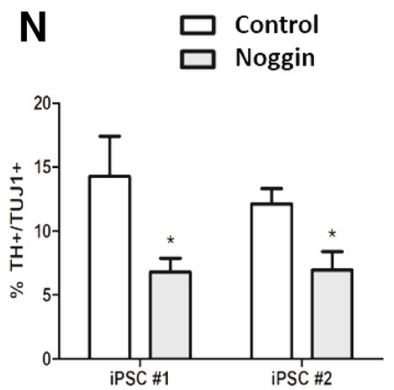

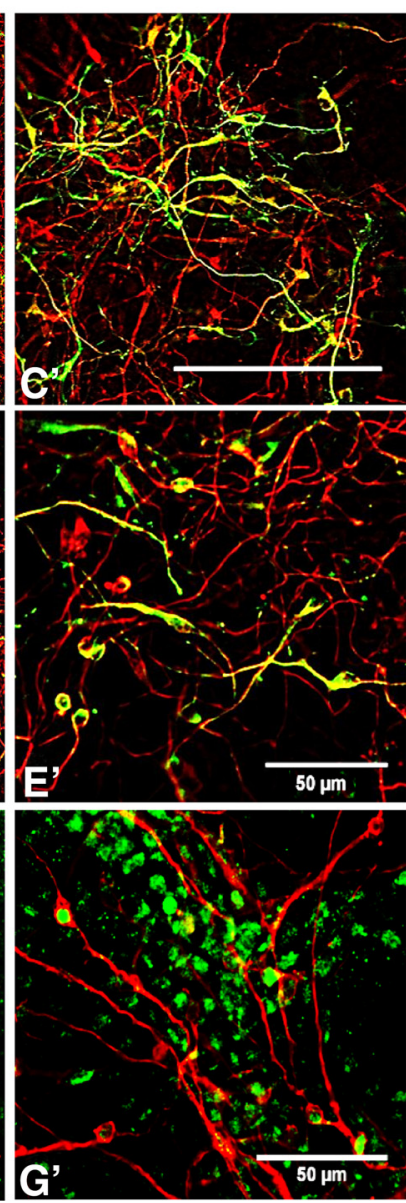

K

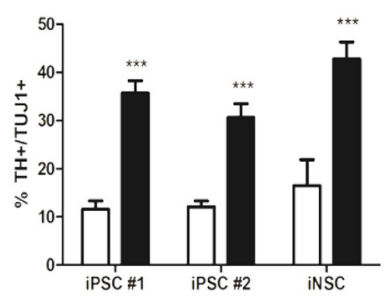

0 믄ol

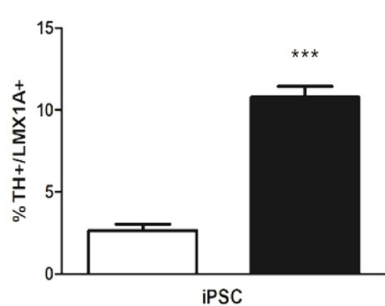

Figure 7. Timed delivery of BMP5/7 during in vitro DA differentiation causes an increase in the yield of mDA neurons. Schematic representation of the protocol used to differentiate iPSC and iNSC to DA neurons (A). Double Immunocytochemistry against TH and TUJ1 in iPSCs and iNSCs either in control or after $30 \mathrm{~d}$ of in vitro DA differentiation treated with BMP5/7 during the maturation phase $\left(\boldsymbol{B}-\boldsymbol{E}^{\prime}\right)$. Double immunocytochemistry against TH and the DA progenitor marker LMX1A $\left(\boldsymbol{F}-\boldsymbol{G}^{\prime}\right)$, the DA markers GIRK2 $(\boldsymbol{H})$ and CALB (I), as well as (Figure legend continues.) 


\section{Postnatal Smad1 ${ }^{\text {Nes }}$ mutants show a predominant loss of $\mathrm{TH}^{+} \mathrm{SOX}^{+}$and $\mathrm{TH}^{+}{ }^{+} \mathrm{GIRK} 2{ }^{+} \mathrm{SN}$ neurons}

At P0, Smad $1{ }^{\text {Nes }}$ mutants still exhibited a significant $28 \%$ reduction in the number of $\mathrm{TH}^{+}$mDA neurons compared with controls (Fig. $6 A-A^{\prime \prime} ; t_{(4)}=3.47,{ }^{*} p=0.026$ ). The number of adjacent POU $4 \mathrm{~F} 1{ }^{+}$red nucleus cells between genotypes was unchanged (Fig. $6 B-B^{\prime \prime} ; t_{(4)}=1.01, p=0.37$ ). Furthermore, $\mathrm{LMX} \mathrm{A}^{+} \mathrm{TH}^{+}$showed a trend reduction by $18 \%$ (Fig. $6 C-C^{\prime \prime}$, $\left.t_{(4)}=1.36, p=0.245\right)$, whereas NURR ${ }^{+} \mathrm{TH}^{+}$were significantly reduced by $30 \%$ (Fig. $6 D-D^{\prime \prime}, t_{(4)}=3.4,{ }^{*} p=0.027$ ). $\mathrm{TH}^{+} \mathrm{PITX}^{+}{ }^{+}$and $\mathrm{TH}^{+} \mathrm{EN}^{+}{ }^{+}$neurons in the mutants were reduced by $29 \%$ and $24 \%$, respectively (Fig. $6 E-F^{\prime \prime}, t_{(4)}=3.49,{ }^{*} p=$ 0.02 for $E^{\prime \prime}$ and $t_{(4)}=3.29,{ }^{*} p=0.03$ for $\left.F^{\prime \prime}\right)$. To investigate whether both VTA and SN neurons are reduced in the mutants, we analyzed the expression of SOX6 and GIRK2, which have been described to be preferentially expressed in $\mathrm{SN}$ mDA neurons (Panman et al., 2014), as well as calbindin, preferentially expressed in the VTA. In $S m a d 1^{\text {Nes }}$ mutants, the reduction in $\mathrm{TH}^{+} \mathrm{SOX}_{6}{ }^{+}$and $\mathrm{TH}^{+} \mathrm{GIRK}^{+}{ }^{+}$neurons was more severe than the decrease in total $\mathrm{TH}^{+}$neuronal populations, as indicated by a significant decrease in the $\mathrm{TH}^{+} \mathrm{SOX}^{+} / \mathrm{TH}^{+}$(Fig. $6 G-G^{\prime \prime}, t_{(4)}=$ $\left.2.8,{ }^{*} p=0.04\right)$ and $\mathrm{TH}^{+} \mathrm{GIRK} 2{ }^{+} / \mathrm{TH}^{+}\left(\right.$Fig. $6 H-H^{\prime \prime}, t_{(6)}=2.48$, $\left.{ }^{*} p=0.048, n=4 \mathrm{WT} ; n=4 \operatorname{Smad} 1{ }^{\mathrm{Nes}}\right)$ ratios in the mutants compared with WT, whereas the $\mathrm{TH}^{+} \mathrm{CALB}^{+} / \mathrm{TH}^{+}$ratio did not differ between the genotypes (Fig. $6 I-I^{\prime \prime}, t_{(4)}=0.89, p=0.424$ ). This particular strong effect on the number of SN neurons in the mutants is likely a consequence of the changes in neurogenesis in these mutants because p-SMAD1/5/8 immunoreactivity, was not enriched in SN neurons at P0 in the WT (data not shown). Finally, the numbers of $\mathrm{TH}^{+} \mathrm{LMX} \mathrm{A}^{+}$and $\mathrm{TH}^{+} \mathrm{NURR}^{+}$neurons remained significantly reduced at P7 (Fig. $6 J-K^{\prime \prime}, t_{(4)}=6.17$, ${ }^{* *} p=0.0035$ for $J^{\prime \prime}$ and $t_{(4)}=6.63,{ }^{* *} p=0.0027$ for $\left.K^{\prime \prime}\right)$.

Together, these data indicate that SMAD1 is required particularly for the formation of $\mathrm{TH}^{+} \mathrm{SOX}_{6}{ }^{+}$and $\mathrm{TH}^{+} \mathrm{GIRK}^{+}$neurons, which are found predominantly in the $\mathrm{SN}$.

\section{BMP5/7 increase the yield of mDA neurons during in vitro differentiation of hiPSCs and iNSCs}

We next aimed to exploit this novel insight into the BMP/SMAD1 signaling role in $\mathrm{mDA}$ formation to modulate directed differentiation of mDA neurons from human iPSCs (lines iPSC\#1 and iPSC\#2) and a previously established iNSC line (Thier et al., 2012; Kadari et al., 2014; Meyer et al., 2015; Kwok et al., 2017). For this purpose, we modified a widely used $\mathrm{mDA}$ differentiation protocol (Reinhardt et al., 2013) that involves FGF8 and the SHH agonist purmorphamine to specify dopaminergic progenitors and a combination of BDNF, GDNF, dbcAMP, and TGFb3 to enhance their maturation. We additionally applied BMP5 and BMP7 during the maturation step and compared the outcome of potential $\mathrm{mDA}$ neuron generation after $22 \mathrm{~d}$ of maturation with non-BMP5/7-treated cultures (Fig. 7A). BMP5/7 treatment re-

(Figure legend continued.) the mature DA marker DAT $(\boldsymbol{J})$ are shown. The percentage of $\mathrm{TH}^{+} \mathrm{TUJ1}^{+}{ }^{+}$in two iPSC lines (iPSC \#1 and \#2) and one iNSC line is twofold to threefold increased in cultures treated with BMP5/7 compared with untreated controls (K). Double immunocytochemistry against TH and TUJ1 in 2 iPSC lines either in control or in cultures treated with Noggin during the maturation phase is shown $(L, M)$. The percentage of $\mathrm{TH}^{+} \mathrm{TUJ} 1^{+}$in two iPSC lines (iPSC \#1 and \#2) is 50\% decreased after blocking the BMP pathway with Noggin compared with untreated controls $(\boldsymbol{N})$. The percentage of $\mathrm{TH}^{+} \mathrm{LMXIA}^{+}$in iPSCs is increased in the treated BMP cultures compared with untreated controls $(\mathbf{0})$. All staining and counting were analyzed after $30 \mathrm{~d}$ of DA in vitro differentiation. Two tailed unpaired Student, $t$ test ${ }^{*} p<0.05$, ${ }^{* * *} p<0.001$. Scale bars indicate $100 \mu \mathrm{m}$ if not specified otherwise. D, Days in vitro. sulted in a strong increase in the numbers of $\mathrm{TH}^{+}$neurons in both human iPSC lines and in iNSC-derived cultures, as measured by costaining for TUJ1 and TH (Fig. $7 B-E^{\prime}$ ). Quantification revealed a significant 2- to 3-fold increase of $\mathrm{TH}^{+}$neurons in BMP5/7-treated cultures compared with untreated cultures (Fig. $7 K$, iPSC \#1: $t_{(6)}=6.759, p=0.0005$; iPSC \#2: $t_{(2)}=39.84, p=$ 0.0006 , iNSC: $t_{(2)}=57.99, p=0.0003$, unpaired $t$ test). Because $\mathrm{TH}$ expression is not restricted to $\mathrm{mDA}$ neurons, we extended our analysis in iPSC-derived cultures to various alternative mDA markers including LMX1A, DAT, GIRK2, and CALB. LMX1A was also analyzed in iNSC-derived cultures. We found numerous cells double-immunoreactive for TH/LMX1A (Fig. $7 F-G^{\prime}$ ), GIRK2/TH (Fig. 7H), CALB/TH (Fig. 7I), and DAT/TH (Fig. 7J), confirming their mDA identity. $\mathrm{TH}^{+}$GIRK2 ${ }^{+}$double-positive cells were found more frequently $(8 \pm 0.6 \%)$ than $\mathrm{TH}^{+} \mathrm{CALB}^{+}(3 \pm 0.4 \%)$ cells. In addition, we used TH/LMX1A costaining for comparative quantification and found fourfold more $\mathrm{TH}^{+} \mathrm{LMX} \mathrm{A}^{+}$cells in BMP5/7-treated iPSC-derived cultures compared with controls (Fig. 7O; $t_{(2)}=80.88, p=0.0002$, unpaired $t$ test). Finally, to test the necessity of BMP5/7 for the generation of mDA neurons, we blocked the BMP pathway during the maturation phase (D8 to D30) using Noggin in both iPSC lines. The results revealed a significant reduction (iPSC \#1: $t_{(2)}=$ 4.482, $p=0.0463$; iPSC \#2: $t_{(2)}=7.207, p=0.0187$, unpaired $t$ test) in the number of $\mathrm{TH}^{+} \mathrm{TUJ}^{+}$in both Noggin-treated cultures (Fig. $7 L-N$ ), indicating a blockade in the generation of mDA neurons. In summary, BMP5 together with BMP7 are able to promote robustly and specifically differentiation of human stem-cell-derived mDA neurons.

\section{Discussion}

We demonstrated that $B m p 5^{-1-} ; B m p 7^{-1-}$ mutants show aberrant MSX1/2 and SHH expression associated with ablated mDA progenitor proliferation and neurogenesis. Furthermore, the conditional inactivation of Smad1 at midgestation impeded differentiation of progenitor cells into mDA neurons by preventing cell cycle exit, particularly of $\mathrm{TH}^{+} \mathrm{SOX}^{+}{ }^{+}$and $\mathrm{TH}^{+}{ }^{+} \mathrm{GIRK} 2{ }^{+} \mathrm{SN}$ neurons. Finally, we found that BMP5/7 increased the efficiency of stem-cell-derived dopaminergic differentiation significantly.

\section{Interactions of BMPs with MSX1/2, SHH, and WNTs in the formation of $\mathrm{mDA}$ neurons}

MSX1/2 mediate as direct BMP/SMAD targets the development of different organ systems (Timmer et al., 2002; Tribulo et al., 2003). MSX1, which is exclusively expressed in the mDA progenitor domain in the ventral midbrain, promotes in cooperation with LMX1A, NGN2 expression, and neural differentiation (Andersson et al., 2013). These data suggest that BMP5/7 regulate $\mathrm{mDA}$ neurogenesis by controlling the expression of MSX1/2 directly.

There are many examples in which SHH and WNTs closely interact with BMPs in the generation of non-mDA neuronal populations. Therefore, an interaction of all three signaling pathways could provide the permissive environment specific for $\mathrm{mDA}$ neurogenesis.

Starting at $\sim$ E8.0, $\mathrm{SHH}$ signaling is important for the formation of the SHH/FOXA2-positive floor plate and $\mathrm{mDA}$ progenitor domain (Ye et al., 1998; Blaess et al., 2006; Perez-Balaguer et al., 2009). However, at the onset of mDA neurogenesis, SHH inhibits floor plate mDA neurogenesis (Joksimovic et al., 2009). $\mathrm{WNT} / \beta$-catenin signaling is necessary and sufficient for antagonizing $\mathrm{SHH}$ and thereby creating a permissive environment for 
mDA neurogenesis (Joksimovic et al., 2009; Tang et al., 2009, 2010). The upregulation of $\mathrm{SHH}$ expression in $B m p 5^{-1-}$; $B m p 7^{-1-}$ mutants therefore indicates that the restriction of $\mathrm{SHH}$ availability by BMPs could provide one mechanism by which BMPs control mDA neurogenesis. Interestingly, the property of $\mathrm{BMP} 7$ to reduce $\mathrm{SHH}$ expression is not limited to the midbrain. Previous experiments have demonstrated that misexpression of BMP7 in the hindbrain, where it is normally not expressed, attenuates the expression of $\mathrm{SHH}$ in the floor plate (Arkell and Beddington, 1997). Moreover, the addition of BMP7 to explant cultures of the hypothalamus downregulated $\mathrm{SHH}$ expression (Manning et al, 2006). One function of BMPs in the development of $\mathrm{mDA}$ neurons is to create a permissive environment for $\mathrm{mDA}$ neurogenesis by restricting $\mathrm{SHH}$ expression.

Examples of crosstalk between WNTs and BMPs in regulating the development of non-mDA neurons raise the possibility that the effects of BMPs on $\mathrm{mDA}$ neurogenesis are mediated through WNTs. However, the unaltered expression of $\mathrm{WNT} / \beta$-catenin in $B m p 5^{-1-} ; B m p 7^{-1-}$ mutants does not suggest that this pathway is downstream of BMPs. Moreover, WNT/ $\beta$-catenin and BMP/ SMAD mutants show distinct phenotypes, further suggesting that $\mathrm{WNT} / \beta$-catenin and BMP/SMAD control $\mathrm{mDA}$ neuron development through separate pathways. In $W n t 1^{-1-}$ and $W n t 1^{-1-} ; W n t 5^{-l-}$ mutants, $\mathrm{TH}^{+}, \mathrm{LMX} 1 \mathrm{~A}^{+}$, and NURR1 ${ }^{+}$ cells are absent in the floor plate and instead are ectopically located laterally (Andersson et al., 2013). The early inactivation of $\beta$-catenin using a SHH-Cre driver leads to the detachment of progenitor cells from the floor plate that become free floating in the enlarged ventricle and a loss of cell adherens junctions (Tang et al., 2009), which we did not observe in our mutants. Similarly, deleting $\beta$-catenin in a temporally controlled manner up to E10.5 using a tamoxifen-inducible R26-CreERT2 driver leads to delaminated cells and loss of ZO1 and $\mathrm{N}$-cadherin immunoreactivity, indicative of cell adhesion defects (Chilov et al., 2011). Importantly, using the nestin-Cre driver, as in our study, to inactivate $\beta$-catenin does not lead to changes in the development of $\mathrm{mDA}$ neurons (Joksimovic et al., 2009). Although we have no indication that the loss of mDA neurons in BMP/SMAD mutants is caused by reduced WNT signaling, our data do not allow us to exclude that the WNT pathway has some role in the BMP/SMAD effects on mDA neurogenesis. Further experiments will be needed to address this issue, including the functional relevance of changes in phosphorylated $\beta$-catenin in BMP mutants.

\section{Early and late effects of BMP/SMAD signaling on mDA neurogenesis}

In contrast to $B m p 5^{-1-} ; B m p 7^{-1-}$ mutants, which do not develop any postmitotic mDA neurons, $\operatorname{Smad} 1^{\mathrm{Nes}}$ mutants show a reduction in the number of these cells. SMAD1/5/8 are the BMPreceptor-regulated SMADs that compose the key components of the canonical BMP signaling cascade (Katagiri and Watabe, 2016). Based on the lack of SMAD8 expression during midgestation and the apparent normal CNS development in Smad8 mutants (Arnold et al., 2006), there is no indication that SMAD8 mediates the effects of BMP5/7 on the formation of mDA neurons. In contrast, Smad1 and Smad5 mutant mice phenocopy aspects of $B m p 5^{-1-} ; B m p 7^{-1-}$ mutants and also die at E10.5 (Chang et al., 1999; Arnold et al., 2006). Moreover, SMAD1 and SMAD5 were shown to function cooperatively in response to BMPs during embryogenesis (Arnold et al., 2006). Therefore, these data suggest that SMAD5 could compensate for the loss of SMAD1 in Smad ${ }^{\text {Nes }}$ mutants, leading to a milder mDA pheno- type of Smad1 ${ }^{\mathrm{Nes}}$ mutants compared with $B m p 5^{-I-} ; B m p 7^{-I-}$ mutants.

Although $B m p 5^{-1-} ; B m p 7^{-1-}$ mutants show a decrease in mDA progenitor cell proliferation at E10.5, Smad1 ${ }^{\mathrm{Nes}}$ mutants show an increase at E12.5. The downregulation of $\mathrm{p}-\mathrm{SMAD} 1 / 5 / 8$ and the unaltered expression of the investigated noncanonical BMP pathway in $B m p 5^{-1-} ; B m p 7^{-1-}$ mutants suggest that the differences in cell proliferation are unlikely to be caused by disruptions of different signaling pathways. Instead, the different phenotypes might be explained by the different time points when we studied the consequences of BMP/SMAD inactivation. This suggests a different response of forming $\mathrm{mDA}$ neurons to the BMP/SMAD pathway at different stages of their development.

There is ample evidence that BMP/SMADs exert different influences during embryogenesis on the development of a cell lineage that are sometimes even opposing. Cell populations that are affected differentially by BMPs during early and later stages of their development include cortical neurons, astroglial lineages (Mabie et al., 1999; Mehler et al., 2000), and neurons in the spinal cord (Yamauchi et al., 2008). Interestingly, there is a dependency of NGN2 expression on BMP7 in the cortex, which is confined to E14.5 (Segklia et al., 2012).

The molecular mechanisms explaining why a cell lineage responds differentially to BMPs during its development are poorly understood. However, there is evidence that the sequential actions of BMP receptors are critically involved in this process (Panchision et al., 2001). Neural precursor cells ubiquitously express BMPR1A from early development on. In contrast, BMPR1B starts to be expressed only later during embryogenesis, at the onset of neuronal differentiation (Panchision et al., 2001). BMPR1B expression is induced by BMPR1A and, interestingly, is repressed by $\mathrm{SHH}$. When BMPR1B is activated, it causes mitotic arrest and thereby limits the number of precursor cells, leading to terminal differentiation in midgestation embryos (Panchision et al., 2001). These data could explain the differences in progenitor proliferation observed in $B m p 5^{-1-} ; B m p 7^{-1-}$ mutants at E10.5 and $S m a d 1^{\mathrm{Nes}}$ mutants at E12.5. At the onset of mDA neurogenesis at E10.5, the reduced BMPR1A/SMAD activation in $B m p 5^{-1-} ; B m p 7^{-1-}$ mutants is responsible for the reduced cell proliferation. During later stages at E12.5, when SMAD1 mediates the differentiating effects of BMPR1B, which we found to be confined in the ventral midbrain to the $\mathrm{mDA}$ progenitor domain, loss of this signaling component attenuates cell cycle exit and differentiation of mDA neurons. Future experiments aiming to understand how BMPR1A and BMPR1B mediate their differential effects on mDA development will provide essential insights into the role of the BMP/ SMAD signaling in the formation of these neurons.

\section{BMP5/7 enhance directed differentiation into mDA neurons in vitro}

Primary cultures derived from rodent embryonic mesencephalon indicate the potential of different BMPs to induce mDA differentiation and promote the survival of these neurons in vitro (Jordan et al., 1997; Hegarty et al., 2014). More recently, BMP7 has been reported to increase the yield of pramipexole-induced mDA neurons from forebrain-derived human neural stem cells and BMP2 was demonstrated to increase the number of LMX1A and FOXA2 immunoreactive cells (Liu et al., 2013; Yang et al., 2016). Many in vitro studies have reported a successful differentiation of mouse and human PSCs toward mDA neurons and demonstrated the efficacy of these cells to integrate and survive in animal models of PD (Kriks et al., 2011; Salti et al., 2013; Grealish et al., 2014; 
Kirkeby et al., 2017). Most of these studies are based on a floor plate protocol, in which neural stem cells are specified and differentiated toward a midbrain fate by triggering SHH and FGF8 signaling pathways to mimic what is known from in vivo midbrain development. However, these research grade protocols face several challenges, especially the considerable variability between experiments and the low purity of PSC-derived $\mathrm{mDA}$ neurons, which lies between $\sim 15 \%$ and 30\% (Kriks et al., 2011; Salti et al., 2013; Kirkeby et al., 2017). This leads us to suggest that essential signaling molecules are still missing in the currently used protocols. In addition, most of these recent protocols inhibit BMP/ SMAD signaling early during the neural induction phase to induce the neural conversion of PSCs (Chambers et al., 2009; Kirkeby et al., 2017).

We found that BMP5/7, if applied in vitro later during the maturation phase, enhanced the formation of $\mathrm{mDA}$ neurons efficiently. Therefore, our data suggest that, although BMP/SMAD inhibition is important for neural conversion at the beginning of the differentiation protocol, it is essential to switch later during the maturation phase to BMP activation. Together, our results on the sequential role of the BMP/SMAD pathway on progenitor proliferation, cell cycle exit, and neurogenesis provide critical information to more efficiently program stem cells to a desired phenotype, increase graft outcome, and reduce side effects after transplantation.

\section{References}

Andersson ER, Saltó C, Villaescusa JC, Cajanek L, Yang S, Bryjova L, Nagy II, Vainio SJ, Ramirez C, Bryja V, Arenas E (2013) Wnt5a cooperates with canonical wnts to generate midbrain dopaminergic neurons in vivo and in stem cells. Proc Natl Acad Sci U S A 110:E602-E610. CrossRef Medline

Andersson E, Jensen JB, Parmar M, Guillemot F, Björklund A (2006a) Development of the mesencephalic dopaminergic neuron system is compromised in the absence of neurogenin 2. Development 133:507-516. CrossRef Medline

Andersson E, Tryggvason U, Deng Q, Friling S, Alekseenko Z, Robert B, Perlmann T, Ericson J (2006b) Identification of intrinsic determinants of midbrain dopamine neurons. Cell 124:393-405. CrossRef Medline

Arenas E, Denham M, Villaescusa JC (2015) How to make a midbrain dopaminergic neuron. Development 142:1918-1936. CrossRef Medline

Arkell R, Beddington RS (1997) BMP-7 influences pattern and growth of the developing hindbrain of mouse embryos. Development 124:1-12. Medline

Arnold SJ, Maretto S, Islam A, Bikoff EK, Robertson EJ (2006) Dosedependent Smad1, Smad5 and Smad8 signaling in the early mouse embryo. Dev Biol 296:104-118. CrossRef Medline

Blaess S, Ang SL (2015) Genetic control of midbrain dopaminergic neuron development. Wiley Interdiscip Rev Dev Biol 4:113-134. CrossRef Medline

Blaess S, Corrales JD, Joyner AL (2006) Sonic hedgehog regulates gli activator and repressor functions with spatial and temporal precision in the $\mathrm{mid} /$ hindbrain region. Development 133:1799-1809. CrossRef Medline

Bond AM, Bhalala OG, Kessler JA (2012) The dynamic role of bone morphogenetic proteins in neural stem cell fate and maturation. Dev Neurobiol 72:1068-1084. CrossRef Medline

Brodski C, Weisenhorn DM, Signore M, Sillaber I, Oesterheld M, Broccoli V, Acampora D, Simeone A, Wurst W (2003) Location and size of dopaminergic and serotonergic cell populations are controlled by the position of the midbrain-hindbrain organizer. J Neurosci 23:4199-4207. Medline

Burgess A, Vigneron S, Brioudes E, Labbe JC, Lorca T, Castro A (2010) Loss of human greatwall results in $\mathrm{G} 2$ arrest and multiple mitotic defects due to deregulation of the cyclin B-Cdc2/PP2A balance. Proc Natl Acad Sci USA 107:12564-12569. CrossRef

Chambers SM, Fasano CA, Papapetrou EP, Tomishima M, Sadelain M, Studer L (2009) Highly efficient neural conversion of human ES and iPS cells by dual inhibition of SMAD signaling. Nat Biotechnol 27:275-280. CrossRef Medline

Chang H, Huylebroeck D, Verschueren K, Guo Q, Matzuk MM, Zwijsen A (1999) Smad5 knockout mice die at mid-gestation due to multiple em- bryonic and extraembryonic defects. Development 126:1631-1642. Medline

Chen HL, Panchision DM (2007) Concise review: bone morphogenetic protein pleiotropism in neural stem cells and their derivatives-alternative pathways, convergent signals. Stem Cells 25:63-68. CrossRef Medline

Chilov D, Sinjushina N, Rita H, Taketo MM, Mäkelä TP, Partanen J (2011) Phosphorylated beta-catenin localizes to centrosomes of neuronal progenitors and is required for cell polarity and neurogenesis in developing midbrain. Dev Biol 357:259-268. CrossRef Medline

Dudley AT, Lyons KM, Robertson EJ (1995) A requirement for bone morphogenetic protein-7 during development of the mammalian kidney and eye. Genes Dev 9:2795-2807. CrossRef

Ferri AL, Lin W, Mavromatakis YE, Wang JC, Sasaki H, Whitsett JA, Ang SL (2007) Foxa1 and Foxa2 regulate multiple phases of midbrain dopaminergic neuron development in a dosage-dependent manner. Development 134:2761-2769. CrossRef Medline

Finelli MJ, Murphy KJ, Chen L, Zou H (2013) Differential phosphorylation of Smadl integrates BMP and neurotrophin pathways through Erk/Dusp in axon development. Cell Rep 3:1592-1606. CrossRef

Grealish S, Diguet E, Kirkeby A, Mattsson B, Heuer A, Bramoulle Y, Van Camp N, Perrier AL, Hantraye P, Björklund A, Parmar M (2014) Human ESC-derived dopamine neurons show similar preclinical efficacy and potency to fetal neurons when grafted in a rat model of Parkinson's disease. Cell Stem Cell 15:653-665. CrossRef Medline

Hegarty SV, O'Keeffe GW, Sullivan AM (2013) BMP-smad 1/5/8 signalling in the development of the nervous system. Prog Neurobiol 109:28-41. CrossRef Medline

Hegarty SV, Collins LM, Gavin AM, Roche SL, Wyatt SL, Sullivan AM, O'Keeffe GW (2014) Canonical BMP-smad signalling promotes neurite growth in rat midbrain dopaminergic neurons. Neuromolecular Med 16:473-489. CrossRef Medline

Huang S, Tang B, Usoskin D, Lechleider RJ, Jamin SP, Li C, Anzano MA, Ebendal T, Deng C, Roberts AB (2002) Conditional knockout of the Smad1 gene. Genesis 32:76-79. CrossRef

Joksimovic M, Yun BA, Kittappa R, Anderegg AM, Chang WW, Taketo MM, McKay RD, Awatramani RB (2009) Wnt antagonism of shh facilitates midbrain floor plate neurogenesis. Nat Neurosci 12:125-131. CrossRef Medline

Jordan J, Böttner M, Schluesener HJ, Unsicker K, Krieglstein K (1997) Bone morphogenetic proteins: neurotrophic roles for midbrain dopaminergic neurons and implications of astroglial cells. Eur J Neurosci 9:1699-1709. CrossRef Medline

Kadari A, Lu M, Li M, Sekaran T, Thummer RP, Guyette N, Chu V, Edenhofer F (2014) Excision of viral reprogramming cassettes by cre protein transduction enables rapid, robust and efficient derivation of transgene-free human induced pluripotent stem cells. Stem Cell Res Ther 5:47. CrossRef Medline

Katagiri T, Watabe T (2016) Bone morphogenetic proteins. Cold Spring Harb Perspect Biol 8: pii: a021899. CrossRef Medline

Kele J, Simplicio N, Ferri AL, Mira H, Guillemot F, Arenas E, Ang SL (2006) Neurogenin 2 is required for the development of ventral midbrain dopaminergic neurons. Development 133:495-505. CrossRef Medline

Kingsley DM, Bland AE, Grubber JM, Marker PC, Russell LB, Copeland NG, Jenkins NA (1992) The mouse short ear skeletal morphogenesis locus is associated with defects in a bone morphogenetic member of the TGF beta superfamily. Cell 71:399-410. CrossRef

Kirkeby A, Nolbrant S, Tiklova K, Heuer A, Kee N, Cardoso T, Ottosson DR, Lelos MJ, Rifes P, Dunnett SB, Grealish S, Perlmann T, Parmar M (2017) Predictive markers guide differentiation to improve graft outcome in clinical translation of hESC-based therapy for Parkinson's disease. Cell Stem Cell 20:135-148. CrossRef Medline

Kriks S, Shim JW, Piao J, Ganat YM, Wakeman DR, Xie Z, Carrillo-Reid L, Auyeung G, Antonacci C, Buch A, Yang L, Beal MF, Surmeier DJ, Kordower JH, Tabar V, Studer L (2011) Dopamine neurons derived from human ES cells efficiently engraft in animal models of Parkinson's disease. Nature 480:547-551. CrossRef Medline

Kwok CK, Ueda Y, Kadari A, Gunther K, Ergun S, Heron A, Schnitzler AC, Rook M, Edenhofer F (2017) Scalable stirred suspension culture for the generation of billions of human induced pluripotent stem cells using single-use bioreactors. J Tissue Eng Regen Med. In press. CrossRef Medline

Liu Q, Pedersen OZ, Peng J, Couture LA, Rao MS, Zeng X (2013) Optimiz- 
ing dopaminergic differentiation of pluripotent stem cells for the manufacture of dopaminergic neurons for transplantation. Cytotherapy 15: 999-1010. CrossRef Medline

Mabie PC, Mehler MF, Kessler JA (1999) Multiple roles of bone morphogenetic protein signaling in the regulation of cortical cell number and phenotype. J Neurosci 19:7077-7088. Medline

Mehler MF, Mabie PC, Zhu G, Gokhan S, Kessler JA (2000) Developmental changes in progenitor cell responsiveness to bone morphogenetic proteins differentially modulate progressive CNS lineage fate. Dev Neurosci 22:74-85. CrossRef Medline

Manning L1, Ohyama K, Saeger B, Hatano O, Wilson SA, Logan M, Placzek M. (2006) Regional morphogenesis in the hypothalamus: a BMP-Tbx2 pathway coordinates fate and proliferation through Shh downregulation. Dev Cell 11:873-885. CrossRef

Meyer S, Worsdorfer P, Gunther K, Thier M, Edenhofer F (2015) Derivation of adult human fibroblasts and their direct conversion into expandable neural progenitor cells. J Vis Exp 101:e52831. CrossRef Medline

Mueller TD, Nickel J (2012) Promiscuity and specificity in BMP receptor activation. FEBS Lett 586:1846-1859. CrossRef Medline

Nouri N, Awatramani R (2017) A novel floor plate boundary defined by adjacent En1 and Dbx1 microdomains distinguishes midbrain dopamine and hypothalamic neurons. Development 144:916-927. CrossRef Medline

Panchision DM, Pickel JM, Studer L, Lee SH, Turner PA, Hazel TG, McKay RD (2001) Sequential actions of BMP receptors control neural precursor cell production and fate. Genes Dev 15:2094-2110. CrossRef Medline

Panman L, Papathanou M, Laguna A, Oosterveen T, Volakakis N, Acampora D, Kurtsdotter I, Yoshitake T, Kehr J, Joodmardi E, Muhr J, Simeone A, Ericson J, Perlmann T (2014) Sox6 and Otx2 control the specification of substantia nigra and ventral tegmental area dopamine neurons. Cell Rep 8:1018-1025. CrossRef Medline

Pattyn A, Morin X, Cremer H, Goridis C, Brunet JF (1997) Expression and interactions of the two closely related homeobox genes Phox2a and Phox2b during neurogenesis. Development 124:4065-4075. Medline

Perez-Balaguer A, Puelles E, Wurst W, Martinez S (2009) Shh dependent and independent maintenance of basal midbrain. Mech Dev 126:301313. CrossRef Medline

Politis M, Wu K, Loane C, Quinn NP, Brooks DJ, Rehncrona S, Björklund A, Lindvall O, Piccini P (2010) Serotonergic neurons mediate dyskinesia side effects in parkinson's patients with neural transplants. Sci Transl Med 2:38ra46. CrossRef Medline

Prakash N, Brodski C, Naserke T, Puelles E, Gogoi R, Hall A, Panhuysen M, Echevarria D, Sussel L, Weisenhorn DM, Martinez S, Arenas E, Simeone A, Wurst W (2006) A Wnt1-regulated genetic network controls the identity and fate of midbrain-dopaminergic progenitors in vivo. Development 133:89-98. CrossRef Medline

Puelles E, Acampora D, Lacroix E, Signore M, Annino A, Tuorto F, Filosa S, Corte G, Wurst W, Ang SL, Simeone A (2003) Otx dose-dependent integrated control of antero-posterior and dorso-ventral patterning of midbrain. Nat Neurosci 6:453-460. CrossRef Medline

Reinhardt P, Glatza M, Hemmer K, Tsytsyura Y, Thiel CS, Höing S, Moritz S, Parga JA, Wagner L, Bruder JM, Wu G, Schmid B, Röpke A, Klingauf J, Schwamborn JC, Gasser T, Schöler HR, Sterneckert J (2013) Derivation and expansion using only small molecules of human neural progenitors for neurodegenerative disease modeling. PLoS One 8:e59252. CrossRef Medline

Saarimäki-Vire J, Peltopuro P, Lahti L, Naserke T, Blak AA, Vogt Weisenhorn DM, Yu K, Ornitz DM, Wurst W, Partanen J (2007) Fibroblast growth factor receptors cooperate to regulate neural progenitor properties in the developing midbrain and hindbrain. J Neurosci 27:8581-8592. CrossRef Medline

Salti A, Nat R, Neto S, Puschban Z, Wenning G, Dechant G (2013) Expression of early developmental markers predicts the efficiency of embryonic stem cell differentiation into midbrain dopaminergic neurons. Stem Cells Dev 22:397-411. CrossRef Medline

Segklia A, Seuntjens E, Elkouris M, Tsalavos S, Stappers E, Mitsiadis TA,
Huylebroeck D, Remboutsika E, Graf D (2012) Bmp7 regulates the survival, proliferation, and neurogenic properties of neural progenitor cells during corticogenesis in the mouse. PLoS One 7:e34088. CrossRef Medline

Sherf O, Nashelsky Zolotov L, Liser K, Tilleman H, Jovanovic VM, Zega K, Jukic MM, Brodski C (2015) Otx2 requires Lmx1b to control the development of mesodiencephalic dopaminergic neurons. PLoS One 10: e0139697. CrossRef Medline

Simon HH, Saueressig H, Wurst W, Goulding MD, O'Leary DD (2001) Fate of midbrain dopaminergic neurons controlled by the engrailed genes. J Neurosci 21:3126-3134. Medline

Smidt MP, Asbreuk CH, Cox JJ, Chen H, Johnson RL, Burbach JP (2000) A second independent pathway for development of mesencephalic dopaminergic neurons requires Lmxlb. Nat Neurosci 3:337-341. CrossRef Medline

Solloway MJ, Robertson EJ (1999) Early embryonic lethality in Bmp5;Bmp7 double mutant mice suggests functional redundancy within the 60A subgroup. Development 126:1753-1768. Medline

Tang M, Miyamoto Y, Huang EJ (2009) Multiple roles of beta-catenin in controlling the neurogenic niche for midbrain dopamine neurons. Development 136:2027-2038. CrossRef Medline

Tang M, Villaescusa JC, Luo SX, Guitarte C, Lei S, Miyamoto Y, Taketo MM, Arenas E, Huang EJ (2010) Interactions of Wnt/beta-catenin signaling and sonic hedgehog regulate the neurogenesis of ventral midbrain dopamine neurons. J Neurosci 30:9280-9291. CrossRef Medline

Thier M, Worsdorfer P, Lakes YB, Gorris R, Herms S, Opitz T, Seiferling D, Quandel T, Hoffmann P, Nothen MM, Brustle O, Edenhofer F (2012) Direct conversion of fibroblasts into stably expandable neural stem cells. Cell Stem Cell 10:473-479. CrossRef

Tilleman H, Hakim V, Novikov O, Liser K, Nashelsky L, Di Salvio M, Krauthammer M, Scheffner O, Maor I, Mayseless O, Meir I, Kayam G, SelaDonenfeld D, Simeone A, Brodski C (2010) Bmp5/7 in concert with the mid-hindbrain organizer control development of noradrenergic locus coeruleus neurons. Mol Cell Neurosci 45:1-11. CrossRef Medline

Timmer JR, Wang C, Niswander L (2002) BMP signaling patterns the dorsal and intermediate neural tube via regulation of homeobox and helix-loophelix transcription factors. Development 129:2459-2472. Medline

Tribulo C, Aybar MJ, Nguyen VH, Mullins MC, Mayor R (2003) Regulation of msx genes by a bmp gradient is essential for neural crest specification. Development 130:6441-6452. CrossRef Medline

Tronche F, Kellendonk C, Kretz O, Gass P, Anlag K, Orban PC, Bock R, Klein R, Schütz G (1999) Disruption of the glucocorticoid receptor gene in the nervous system results in reduced anxiety. Nat Genet 23:99-103. CrossRef Medline

Veenvliet JV, Smidt MP (2014) Molecular mechanisms of dopaminergic subset specification: fundamental aspects and clinical perspectives. Cell Mol Life Sci 71:4703-4727. CrossRef Medline

Vernay B, Koch M, Vaccarino F, Briscoe J, Simeone A, Kageyama R, Ang SL (2005) Otx2 regulates subtype specification and neurogenesis in the midbrain. J Neurosci 25:4856-4867. CrossRef Medline

Yamauchi K, Phan KD, Butler SJ (2008) BMP type I receptor complexes have distinct activities mediating cell fate and axon guidance decisions. Development 135:1119-1128. CrossRef Medline

Yang H, Wang J, Wang F, Liu X, Chen H, Duan W, Qu T (2016) Dopaminergic neuronal differentiation from the forebrain-derived human neural stem cells induced in cultures by using a combination of BMP-7 and pramipexole with growth factors. Front Neural Circuits 10:29. CrossRef Medline

Ye W, Shimamura K, Rubenstein JL, Hynes MA, Rosenthal A (1998) FGF and shh signals control dopaminergic and serotonergic cell fate in the anterior neural plate. Cell 93:755-766. CrossRef Medline

Zetterström RH, Solomin L, Jansson L, Hoffer BJ, Olson L, Perlmann T (1997) Dopamine neuron agenesis in Nurr1-deficient mice. Science 276: 248-250. CrossRef Medline 